\title{
CABLE-STAYED STRUCTURES FOR PUBLIC AND INDUSTRIAL BUILDINGS
}

\author{
KRIVOSHAPKO S.N. \\ Peoples’ Friendship University of Russia (RUDN University), Moscow, Russia
}

\begin{abstract}
Cable-stayed structures are simple in assembling, light in weight, safe in maintenance, and often possess the architectural expressiveness. Today's cable-stayed structures erected in Germany, France, Italy, Japan, Singapore, USA, South Korea, Australia, and other countries are recognized as unique and innovative structural solutions. Unique first-of-its-kind systems and the well-known structures and buildings of all types, which have practical importance and novelty and were marked by the rewards of professional associations or were passed into the top lists of journals, are presented in the paper. But there is no current classification of cable-stayed structures till present time. New classification of cable-stayed structures containing five groups or ten sub-groups of considered structures is offered. It is impossible to present all meaningful cable-stayed structures in one paper but every sub-group is illustrated by specific notable examples. The principal information on the 90 remarkable cable-stayed public and industrial buildings are submitted for consideration and a special table with the indication of country, architects, and year of erection of these structures was compiled first. The existence of such cable-stayed structures as "suspended bridges" of two types is indicated but their description is not given, because it is the subject of analysis for bridge engineers. The 58 references presented in the manuscript will help to obtain additional information.
\end{abstract}

Keywords: special structures, cable-stayed structure, cable-stayed roof structure, guyed mast, green roof, open cables

\section{ВАНТОВЫЕ КОНСТРУКЦИИ ОБЩЕСТВЕННЫХ И ПРОМЫШЛЕННЫХ ЗДАНИЙ}

\author{
КРИВОШАПКО С.Н. \\ Российский университет дружбы народов, Москва, Россия
}

\begin{abstract}
Аннотация. Вантовые конструкиии просты в сборке, мало весят, Cable-stayed structures are simple in assembling, light in weight, безопасны в обслуживании и часто привносят архитектурную выразительность. В настоящее время вантовые конструкции, возведенные в Германии, Франции, Италии, Японии, Сингапуре, США, Южной Корее, Австралии и других странах, признаны как уникальные и инновачионные конструктивные решения. В статье представлены уникальные, первые в своем роде конструкичи, которые имеют практическую значимость и новизну и были отмечены наградами профессиональных сообществ или вошли в топ-лист журналов. Однако к настоящему времени отсутствует классификация вантовых конструкиий. Предложена новая классификация вантовых сооружений, содержащая пять групп или десять подгрупп рассматриваемых конструкиий. Не представляется возможным представиь все значимые вантовые сооружения в одной статье, однако каждая подгруппа проиллюстрирована соответствующим примером. $B$ статье впервые представлены приниипиальные сведения о 90 значимых вантовых общественных и промышленных зданиях. В табличной форме представлена информация о стране, архитекторе и годах строительства этих сооружений. Отмечено существование таких вантовых сооружений, как подвесные мосты двух типов, однако этот вопрос относится к специфической области мостостроения.
\end{abstract}

Ключевые слова: специальные сооружения, вантовые сооружения, вантовые конструкции покрытия, мачта, «зеленая» кровля, открытые тросы. 


\section{Introduction}

R. Bradshaw et al [1] suppose that special structures are landmarks and testimonials to the achievements of the structural engineering profession. They include the following types of structures: space frames or grids; cable-and-strut and tensegrity; air-supported or air-inflated; selferecting and deployable; cable net; tension membrane; lightweight geodesic domes; folded plates; and thin shells. But R. Bradshaw et al did not point out the cable-supported structures. Massimo Majowiecki [2] from University of Venice, Italy, writes that cable structures include cable-stayed roofs, suspended roofs, cable trusses, and single and multilayer nets. Zagorkov [3] marked out three groups of cable-stayed structures orientating by the dominating state of bearing metal pylons. Kloiber Lawrence A. et al [4] show that there are several types of cable-supported structures, but they can generally be sorted into two categories, cable-suspended and cable-stayed structures. In cable-suspended structures, the draped cables are the main supporting element of the structure, and their curvature is a major factor in the load carrying capacity of the system [4]. Cable-stayed structures are special structures containing open tensile steel wire ropes. Their curvature is equal to zero practically. Cable-supported structures attracted the attention of architects and civil engineers in the $20^{\text {th }}$ and $21^{\text {st }}$ centuries and can obtain larger recognition in the future, but there is no current classification till present time.

\section{General information and definitions}

In suspended structures, steel wire ropes, cables, chains, rolled metal and sheet membranes resist the external load and they work only for tension. In the cable-stayed suspension systems, guys (threads) or wire rope plane or space trusses support rigid elements (beams, plates, arches, frames) in the design position. Covering materials (roofing) are placed on these rigid elements working in bending. Besides suspended cable-stayed systems, cable-stayed structures include in themselves also the structures containing cables as the stabilizing elements or creating geometrical image of the erection. One can consider that the ideal thread is the simplest cable-stayed structure because it does not resist the bending and torsion. But architects consider that cable-stays, staying always straight, do not belong to the class of elastic threads [5].

The wire rope suspension structures (cable-suspended structures) differ from the cablestayed suspension systems because the covering elements in them are placed directly on the wire ropes or on the wire rope net. Stay suspension cables (guys) are called sometimes open cables, or open wire ropes, or tensioned straight cables [6] and that is why cable-stayed structures are called also roof structures with pylons and open cables. This term is used sometimes by some Russian engineers. The classification of wire rope suspension structures can be found in [7].

Although all cable-supported structures are effective for wide span, each system has its own distinct characteristic which makes it attractive for certain conditions and more suitable for particular architectural application. This paper focuses only on the second type of cable-supported structures that is cable-stayed structures.

\section{The classification of cable-stayed structures}

Due to the fact that guys are open wire ropes, the following classification of cable-stayed structures according to their design features, purposes, and methods of strength analysis is suggested:

1) cable-stayed roof structures (straight tensioned cable roof structures $[6,8])$ :

- suspended cable-stayed roof structures supporting tent membranes in particular points;

- suspended cable-stayed structures with single bearing pylon (pillar);

- suspended cable-and-rod roof structures with bearing pillars placed at one or several rows;

- suspended cable-and-arch roof structures;

- cable-stay supported cantilevers; 
2) cable-stays for stabilization of contour rigid elements of tent membranes;

3) masted structures with cable-stay elements:

- masted structures with cable-stays ensuring stability of the structures;

- masted structures in the form of one-sheet hyperboloid with cable-stays coinciding with rectilinear generatrixes of the surface;

4) special combined suspended cable-stayed roof structures;

5) suspended bridges.

A simplified version of the classification presented here was submitted for consideration in a paper [9]. It should be noted, that cable-suspended structures were not inscribed in the classification although they together with membrane roofs can make up a larger class of suspended roof structures. Yermolov [5] has resulted the main front views of location of pillars and guys in suspended cable-androd and suspended cable-and-arch roof structures in the tabular form (Fig. 1).

The names of cable-stayed structures used

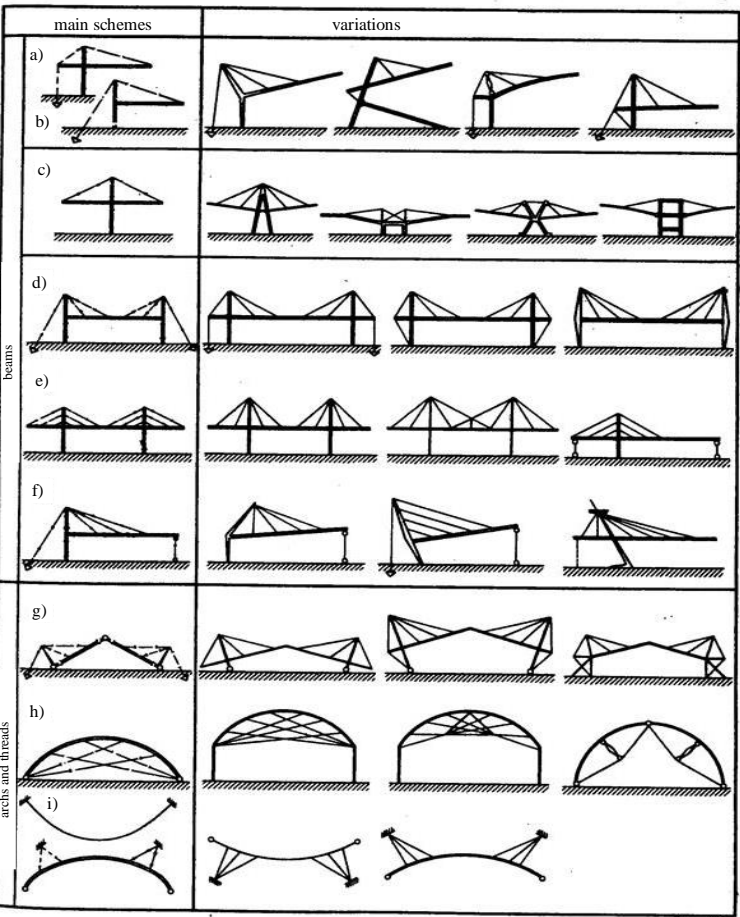

Figure 1 - The front views of pillars and guys in suspended cable-stayed roof structures

in the classification have synonyms. Other authors can use other names because there are no settled exact wordings for some types of cable-stayed structures.

\section{Brief information on design considerations in cable-stayed structures}

Wire rope suspension structures and cable-stayed suspension systems allow overlapping spans more than 200 meters, but usually the overlap spans range from 50 to $150 \mathrm{~m}$. As a rule, guys are single or double twisted wire ropes made of high-strength wires with the diameter of 4-6 mm. Wires with smaller diameters are not recommended because of their low corrosion resistance [10]. Depending on the type of touching wires between themselves, the steel wire ropes are divided into the ropes with a point (PT) and linear (LT) touching of the wires. The ropes of the PT type are more rigid than the ropes of the LT type.

Inclined guys diverge from the upper points of the pylons as rays. Guys are often arranged parallel to each other (the "harp" scheme). The slopes of the cable-stays have to be larger than $30^{\circ}$, but in special cases up to $25^{\circ}$. The ends of the cables are pushed into the sockets. There are two types of sockets, open sockets and closed sockets.

It is believed that the cable-stays retain the rectilinear shape. So, they can be made of rods, strips, profiles, and so on. The nonlinear effects of cables are generally less dramatic in cable-stayed structures than in cable-suspended structures [4]. The stay suspension cables are placed outside in the open air space, so they require the effective proof against possible corrosion. Galvanizing, anticorrosion paint, plastic paintworks are usually used as protective means. Measures taken for protection of the stay suspension cables against corrosion will be discussed on specific examples of real structures in the next parts. Design decisions used for the units of passing of cables through the roofing are quite complex and they require a high-quality execution of the work guaranteeing the lack of leakage. This factor influences on the working properties of cable-stayed roof structures.

Very long unsupported spans, rapid installation, lightweight structures, aesthetic, competitive in comparison to steel roof structures are the benefits of cable-stayed roof structures.

Consider the real-life examples of cable-stayed structures, erected at the late twentieth and early twenty-first century, according to the classification proposed in the paper. The very interesting 
information on the suspension structures realized in the projects or in real structures built in the XIX and XX centuries can be found in a book [11].

\section{Cable-stayed structures}

5.1. Cable-stayed roof structures

points

Suspended cable-stayed roof structures supporting tent (fabric) membranes in particular

The barrel-shaped roof of the Lawn Tennis Association's National Tennis Centre in London illustrates well the erections of this type. The tent membrane overlaps the space of $11,500 \mathrm{~m}^{2}$. Volume structures of various purposes are placed under this roof. Six courts for tennis, a specialized gymnasia, a sports clinic, rooms for coaches, and so on are among them. One of the threedimensional structures is covered by a tent structure which is supported by a system of guys with two tubular pillars (Fig. 2).

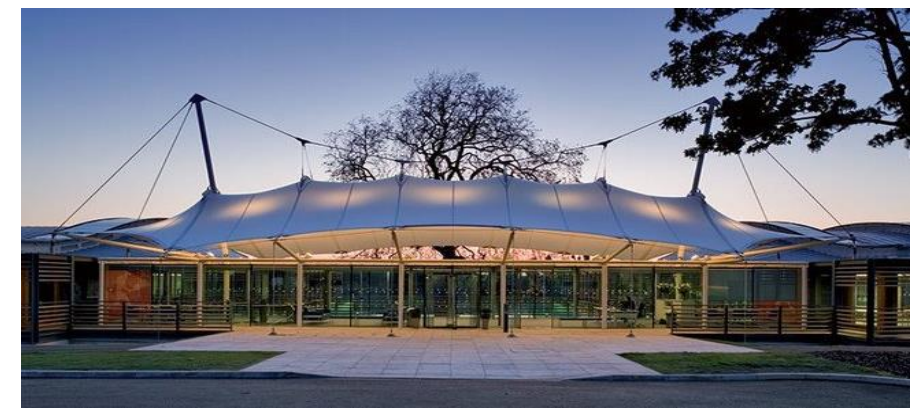

Figure 2 - The Lawn Tennis Association's National Tennis Centre (Hopkins Architects), London, UK, 2008

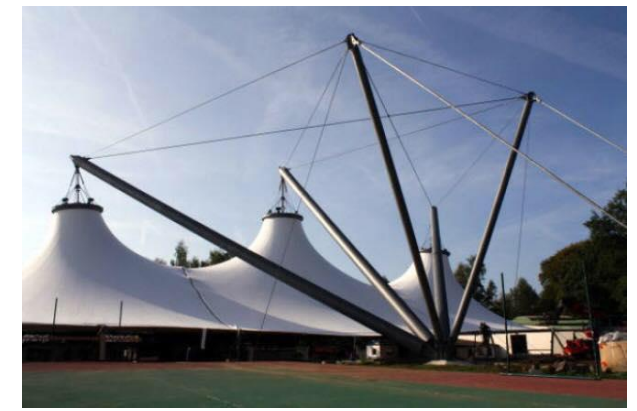

Figure 3 - Beaufort Ice Skating Rink, Beaufort, Luxembourg, after 2011

A tent structure of the summer cafes hung up to the central pillar with the help of the guys may be also included in subgroup of suspended cable-stayed roof structures supporting fabric membranes in particular points [9]. The edges of the tent are fixed to the aluminum profile with the help of the steel staples or plastic straps. The application of the cables gives the possibility to decline massive weight frame with a heap of metal trusses and beams, which would override the lightness of tent covering [F. Nadyozhniy, http://www.teniradi.ru].

Structures of the type considered can be ascribed both to tent structures and to suspended cable-stayed roof structures. The innovative structural solution of Grande Arche of La Défence in Paris presented by a Danish architect J. Otto Spreckelsen won the international competition of the Grande Arche. This structure of 110 meters of height contains also the tent membrane suspended by cable-stays from the wide and tall hypercube made of concrete and marble. This structure is one of varieties of suspended cable-stayed roof structures supporting fabric membranes in particular points.

Beaufort Ice Skating Rink in Beaufort, Luxembourg, was opened in 1969. Since 2011, it is covered by a tent and becomes a suspended cable-stayed roof structure (Fig. 3). NSC Kuala Lumpur tent roof over swimming stadium, Malaysia, completed in 1997, is hung up to the single inclined pillar in several points with the help of the guys.

Additional examples of suspension tent-and-cable structures are given in [12, 13].

Coverings made of not tent materials but resisting only tension are ascribed to the same group of suspended cable-stayed roof structures. The covering of the Olympic stadium in Munich, Germany, is a striking example of these structures. It was built in 1972 and designed by the architects Otto Frei and Günter Behnisch.

\section{Suspended cable-stayed structures with single bearing pylon}


The mushroom-shaped pavilions erected for the exhibition of flowers in Kassel in 1955 (Fig. 4) were the first representatives of this type of suspended cable-stayed roof structures. But they become irrational if they have large spans.

Ontario Place Pods in Toronto, Canada, look like a model of the mushroom-shaped pavilion shown in Fig. 4. The pods are supported on four pipe columns, rising 105 feet $(32 \mathrm{~m})$ above the lake. Ontario Place Pods are anchored into the ground under the water. Tension cables support the short-span trusses. The Ontario government decided to close the park in 2011.

The covered skating Center "Krylatskoe" in Moscow, Russia, opened in 2006 is the Europe's largest

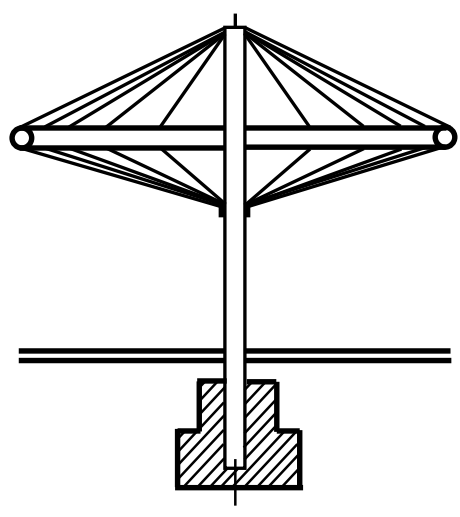

Figure 4 - A model of the mushroom-shaped pavilion

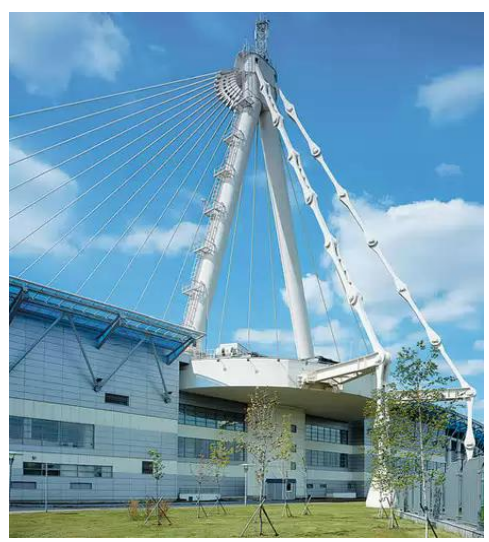

Figure 5 - The single pylon of the Ice Palace in Moscow, Russia structure of this type. Here, the covering is hung from a $\wedge$-shaped pole placed on the axis of symmetry of the skating center with an offset along this axis (Fig. 5). Two backstays of the pillar (the anchoring wires) ensure the balance of the whole cable-stayed system [14]. An emergency situation caused by the sagging roof of the Ice Palace raised at the end of 2007. It was proved that a manufacture defect of the metal structures caused the emergency. A similar project of suspension of a steel rod rectangular plate of covering with the help of cable-stays to a single vertical steel pylon was applied to the structure in La Rachel, France (Ré Island Toll Gate, La Rochelle, Poiton-Charente). Taking into account the offset of the pylon in the direction of the center of the covering plate, two corners of the plate that are the closest to the pylon, were anchored into the ground.

The cable net roofing of the Olympic Stadium in Montréal is hung from the inclined $175 \mathrm{~m}$ high tower La Tour de Montreal but the roof is only $52 \mathrm{~m}$ above the field of play. This is the highest inclined tower (Fig. 6). The futuristic round building with a suspended cable-stayed roof which is hung from the $\Pi$-shaped single bearing pylon with the help of ten of stays is a part of a complex of buildings of Convention Center, Hanover, Germany (Fig. 7). At the annual meeting of the European Convention for Construction Steelwork in 1991, the designers of this complex were awarded the European Steel Construction Prize.

An experimental study on model of a cable stayed pavilion roof, proposed for a university complex in Trinidad, West Indies, has been carried out at the National Wind Tunnel Facility, IIT Kanpur [15]. Two towers are the main supports from which cables, in turn, support two roofs. Due

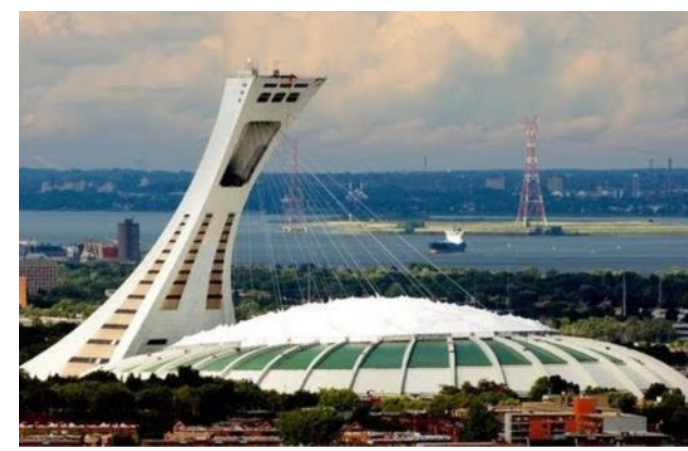

Figure 6 - The single pylon (the tower) of the Olympic Stadium in Montréal, Canada, 1976

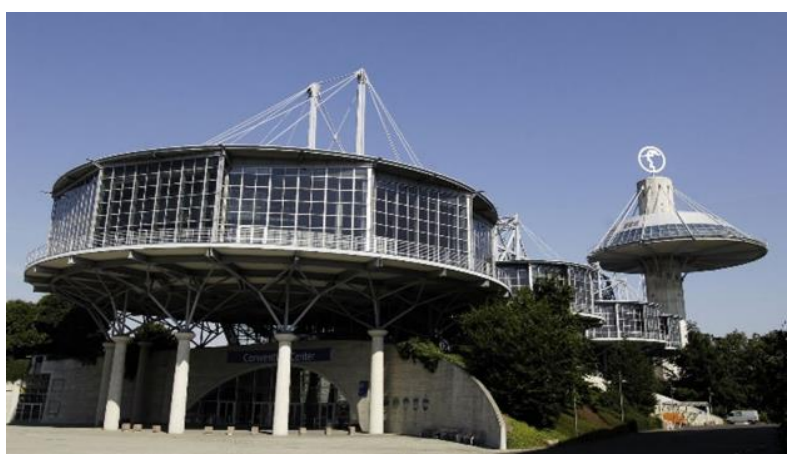

Figure 7 - Convention Center, Hanover, Germany, 1989 
to the shape and location of the cable stayed roofs, the designer was interested in deter-mining the most adverse wind loading conditions that the structure might be subjected at design wind speed.

A detail design of a civil aircraft museum in Sestoretzk, Russia (Fig. 8), foresees the application of the large span covering supported by diagonal guys attached to a single pylon [16].

Juventus Stadium in Turin, Italy, has two huge steel supports of $86 \mathrm{~m}$ high. But it is desirable to add on this erection to the category of suspended cable-stayed roof structures with single bearing pylon, taking into account that pylons work irrespective of each other.

\section{Suspended cable-and-rod roof structures with bearing pillars placed at one or several rows}

This subgroup of cable-stayed roof structures is the easiest and most commonly used. These covers are called often cable-and-beam roof structures. Rigid beam is supported here by the guys at one or several points. The guys are attached to the posts that are braced in both transverse and longitudinal directions.

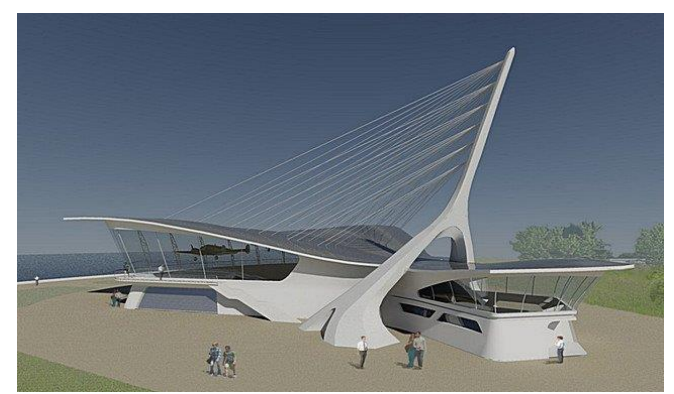

Figure 8 - A detail design of a museum of civil aircraft (Sestoretzk, Russia)

The UK Pavilion at EXPO-70 in Osaka, Japan, is a one-row system from four steel frames of $34 \mathrm{~m}$ high. The bearing roof structure and walls are hung from the $\Pi$-shaped frames with the help of the cable hangers.

A single-row system from three pillars with the cable-stays attached at the same level and holding up the roof in two directions was described in a paper [17] as an example of one of cable-stayed buildings in Rome (Italtubi warehouse), Italy. A single-row system from 13 pillars with two inclined rigid elements and with one gay cable was applied in But-Pôle Atlantis, Saint Herblain, France. The inclined rigid elements and gay cables were attached at the same level but they were placed in perpendicular planes. The inclined elements and pillars are in transverse parallel planes, but pillars and gay cables are along the longitudinal axis of the building [18].

The cable-stayed roofs of Atatürk Stadium in Istanbul, Turkey, completed in 2002 (architects A. Zublena and M. Macary) [19], Yishun Stadium with the $32 \mathrm{~m}$ cantilevered structure completed in 1992 (the first of its kind in Singapore) [20], the canopy in the main entrance to EXPO-89 with main total dimensions $47 \mathrm{~m} \times 33 \mathrm{~m}$ in Yokohama, Japan; Eastville Tesco (Tesco Supermarket) in Bristol, UK, can be also related to these suspended cable-and-rod roof structures with bearing pillars placed at one row. The main structural system of Conference Center in Smart Village, Giza, Egypt is a space truss roof supported by cables connected to six steel masts also placed at one row. It was constructed in 2002. The roof loads, wind and seismic loads were taken into account. The optimization procedure managed to decrease the structure total weight by about 16.88 tons.

The unique five-level building of "Kaliningrad Stadium", Russia, having rectangular plan with rounded corners was designed by "Crocus International" and erected in 2018. The project of Architectural Bureau "Wilmotte \& Associes Sa" was assumed as a basis of this stadium. 32 pillars with the rod-stays supporting the roof over the stands (see Fig. 1, the first line and the first column) are placed in a single row along the oval closed curve.

A strength analysis of a shed over the petrol station with cable-stays was fulfilled by the company ARHIKOM with the help of a module APM Structure3D. This petrol station was built in Nizhnevartovsk, Russia, in 2004 (Fig. 9). It is a one-row system from two pillars [21].

An unusual building of the PA Technology Center in Princeton (NJ, North America) with one row of bearing pillars was designed by the architect Richard Rogers in the style of "high tech» (the high tech architecture movement) during period of its highest popularity from 1960 to 1990. The Center was built in 1982 [22]. The architect abandoned traditional columns and beams in favor of the steel structures, usually used in bridge construction and in the design of tower cranes. The 
modules (blocks) of the building were prefabricated in the factory and this decision significantly reduced the deadline for the completion of a project.

A cable-stayed roof structure of one building of Bayfront Convention Center in Erie (Barton Malow Co., USA) contains four bearing pillars placed also at one row. Five cable-stays attached at the same level to the same pillar carry the roof block at five points around the pillar. Barton Malow Co. shepherded the project to completion in February 2008 and garnered a 2009 Aon Build America Award for best construction management. A cable-stayed roof structure of Champratel Bus and Tramway Depot in Clermont-Ferrand, France, contains four bearing pillars placed at one row. Seven cable-stays attached to every pillar carry the roof block at seven points around the pillar.

Let us pay attention to an interesting trend in the

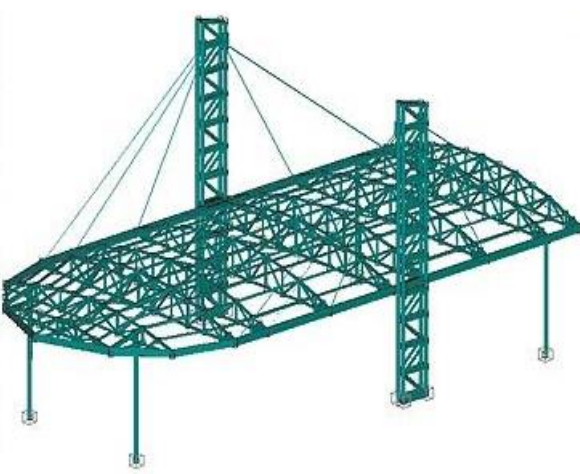

Figure 9 - The solid body model of a petrol station with cable-stays for a module APM Structure3D, “ARHIKOM”, Russia architecture of suspended cable-stayed roof structures such as "green roofs". For example, in the South France in Leone, architects Jourda and Perraudin designed the suspended roof in the form of the umbrella surface covering an area of 8,000 $\mathrm{m}^{2}$. Wild flowers and grass grow on the roof. There are lecture-rooms of the International School under this roof. The suspended cable-androd roof with bearing pillars placed at several rows with a green roof in Stuttgart, Germany (Fig. 10) covers the larger area. Now, there is the public

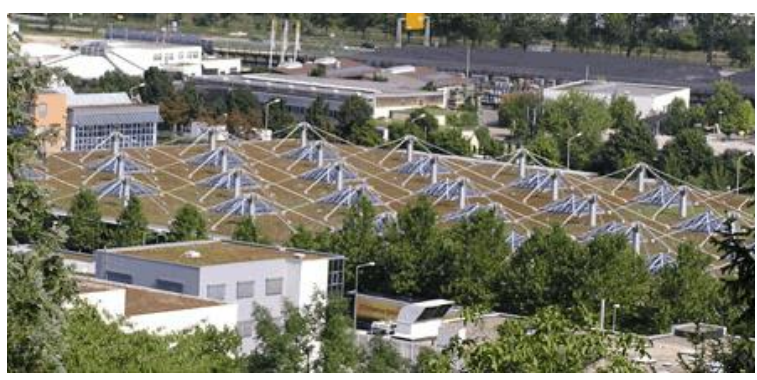

Figure 10 - Green roof Service LLC, Stuttgart, Germany (photo by G. Breuning) transportation company inside.

Suspended cable-and-beam roof structures are often categorized into three groups:

a) suspended roof structure with a transverse cable-stayed system and with two rows of bearing pillars (Fig. 11);

b) suspended roof structure with a transverse cable-stayed system and the central row of bearing pillars (Fig. 12);

c) suspended roof structure with a longitudinal cable-stayed system with one or more rows of bearing pillars (Fig. 13).

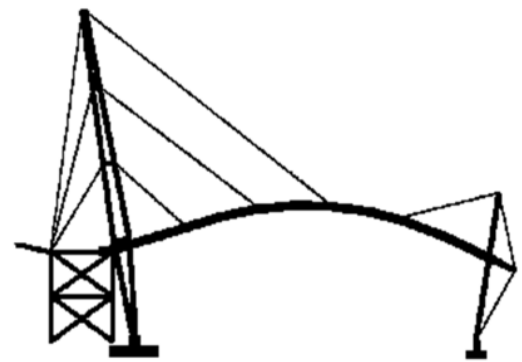

Figure 11 - The design consideration of the Gerald Rather Athletics Center of the University of Chicago, USA

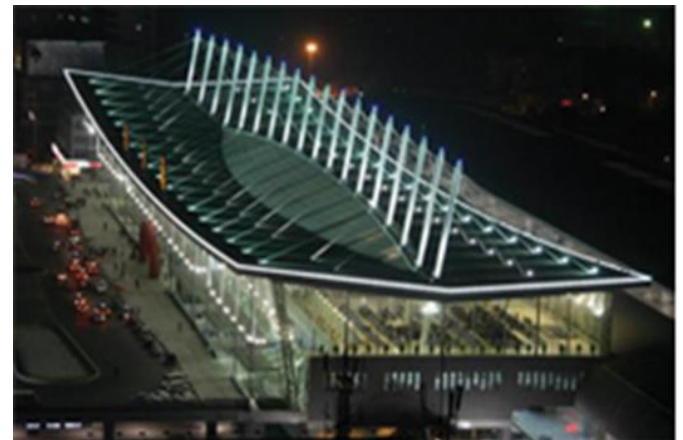

Figure 12 - A roof structure of railway station in Nanjing, Jiangsu Province, China

The Eastleigh Tennis Center located near Southampton, UK, and designed by the Architects, Euan Borland Associates and Buro Happold Consulting Engineers is an example of the using longitudinal wavy beam supported by the cable-stayed system with one row of bearing pillars [23]. 
Two buildings are covered by industrial fabrics. A key factor in the design of the roofs was that they needed to provide lighting comparable to daylight at a cost less than a traditional glass roof.

The first suspension roof structure with the transparent plastic roofing was built over a bus stop in Milan, Italy, in 1949. The sloping roof is hung from sloping bearing pillars with the help of a system of cable-stays. The equilibrium is achieved by special braces which are attached to the edges of the cover.

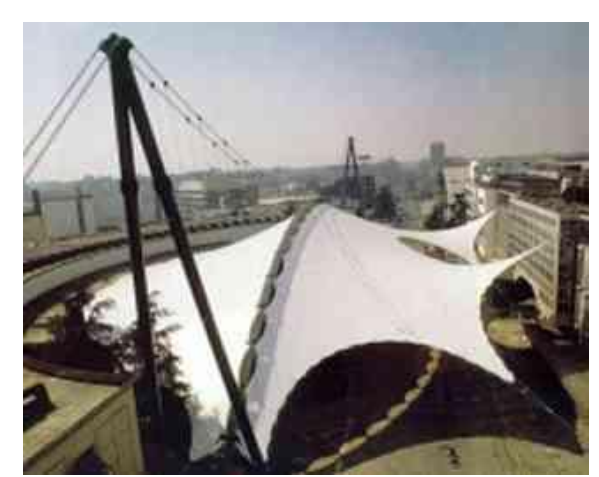

Figure 13 - A suspended roof structure with the longitudinal cable-stayed system, Milan, Italy

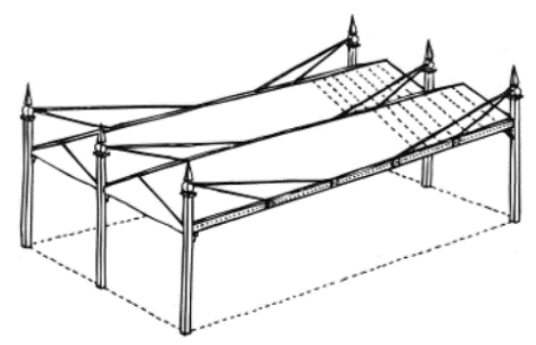

Figure 14 - The project of Ch. MakIntosh for the Green House, 1853

The Gerald Rather Athletics Center of the University of Chicago is a unique first-of-its-kind asymmetrically supported cable-stayed system with composite tapered masts that are stabilized by back-stay cables, anchored in place by massive concrete counterweights (Fig. 11). An innovative solution gave a chance to cover the large area of over $20,000 \mathrm{ft}^{2}$. According to the authors of the project (Cesar Pelli \& Associates teamed with OWP/P), refusal of the application of reinforced concrete gave a number of advantages, including reduced cost of the structure. The masts are inclined at an angle $10^{\circ}$ with the vertical. Both aesthetic reasons and the conditions of work of the asymmetrical structure [4] were taken into account. Each pillar holds 3 curved beams. Three cables are fixed to the high pillar and one cable is fixed to the small one. Apart from its award-winning design, the Ratner Athletics Center is also known for its world-class facilities.

A suspended roof over the Olympic stadium in Squaw Valley, USA, can accommodate 8,000 spectators. Its dimensions in plan are $94.82 \mathrm{~m} \times 70.80 \mathrm{~m}$. The suspended roof consists of eight pairs of inclined box girders with variable cross-sections supported by the cable-stays. The cable-stays are based on 2 rows of the pillars which are installed every $10.11 \mathrm{~m}$. The beams were placed on the inclined box girders and after the plates with box-section and length of $3.8 \mathrm{~m}$ were laid on the beams. The carrier cables are steel wire ropes of $57 \mathrm{~mm}$ in diameter [24]. The diagram of installation of the pillars and guys of the stadium in Squaw Valley city is presented in Fig. 1, the sixth line, the second column. The diagram of a cable-stayed roof structure with three hinges roofed over the ice rink in Braunschweig, Germany, is shown in Fig. 1 in the sixth line, in the third column. The diagram of a cable-stayed roof structure of Railway Station in Tilburg, Holland, is presented in Fig. 1 in the sixth line, in the second column. This station has three pairs of inclined pillars.

The classical design of a suspended roof structure with a transverse cable-stayed system and two rows of bearing vertical pillars was embodied in the roof structure of the flower market «Pescia flower market», Italy [17].

As an example of a suspension roof structure with transverse cable-stayed system and the central row of bearing pillars, one can take the cable-stayed roof structure of the railway station in Nanjing city, Jiangsu Province, China, Fig. 12; Ocean Terminal in Piraeus, Greece, opened in 1972; INMOS microprocessor factory with nine pillars located in one row and a spine of $7.2 \mathrm{~m}$ wide and a $106 \mathrm{~m}$ central corridor in Newport, UK [3]. The diagram of the INMOS microprocessor factory is shown in Fig. 1 in the second line, in the last column but the real building has the horizontal truss beams [25]. The diagram presented in Fig. 1 in the fourth line in the third column was used in Altos de la Vanega Metro Station in Maracaibo, Zulia, Venezuela, completed in 2006.

In 1853, Charles MacIntosh in his work "Book of the Garden" proposed for the first time the design of a suspended roof structure with the longitudinal cable-stayed system for the Green 
Theatre. Here, each stiffening girder is supported by four guys which were planned to fix to the vertical pillars (Fig. 14). However, Ch. MacIntosh did not provide anchoring wires for the columns (masts) and that is why, the project was not realized in nature [11]. But a cable-stayed frame, that is the main supporting structure of a wide-span sport hall preliminarily designed by MacGinley and Đuran [26], is free from this defect. A model of the frame is shown in Fig. 1, the third line and the third column.

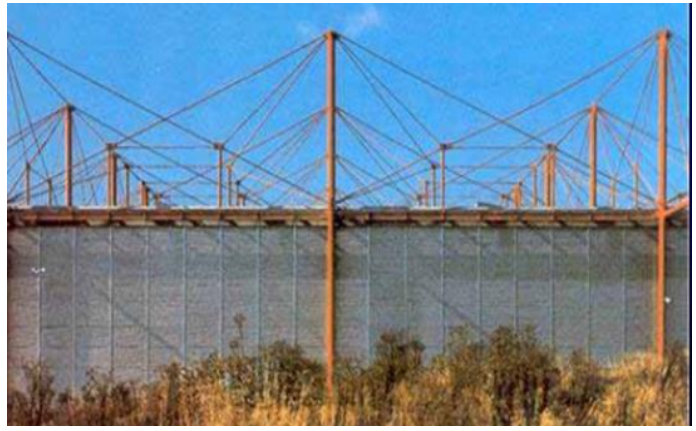

Figure 15 - Fleetguard factory Quimper, France

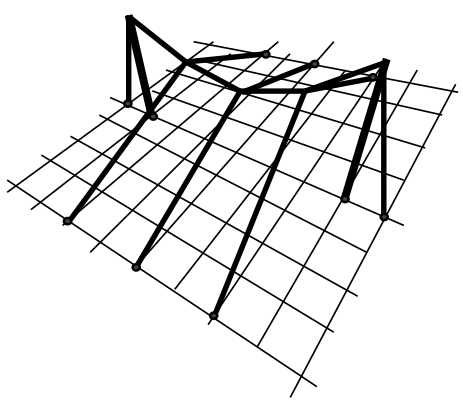

Figure 16 - A model of stable cable-stayed structure

A suspended roof over a paper factory in the city of Mantua, Italy, was built in 1963. It consists of six longitudinal stiffening girders with the $163 \mathrm{~m}$ span with the symmetric $43 \mathrm{~m}$ cantilevers. The roof is suspended with the help of four steel cables to two reinforced concrete pylons of $45 \mathrm{~m}$ high. The building resembles suspension bridge from the outside [24]. The chosen solution of Oxford Ice Rink, UK, uses a central longitudinal spine beam made from a pair of rectangular hollow sections, and spanning up to $15 \mathrm{~m}$ between overhead supports. Every end of the central longitudinal beam is suspended by two tie-rods at two levels from one pylon.

A cable-stayed roof structure of Fleetguard factory Quimper in France (Fig. 15) and the presented model of stable cable-stayed structure (Fig. 16) [27] can be picked out into the new fourth category of cable-stayed roof structures in the described class of the suspended cable-beam roof structures. This fourth category can be called «suspended multidirectional roof structure with transverse-and-longitudinal cable-stayed system». The roof structure of a factory in France (Fig. 15) designed by architect Richard Roger and engineer Ove Arup consists of 25 modules of 18 $\mathrm{m}^{2}$ area. Every roof module contains stiffening beams placed in two directions and it is slinged by

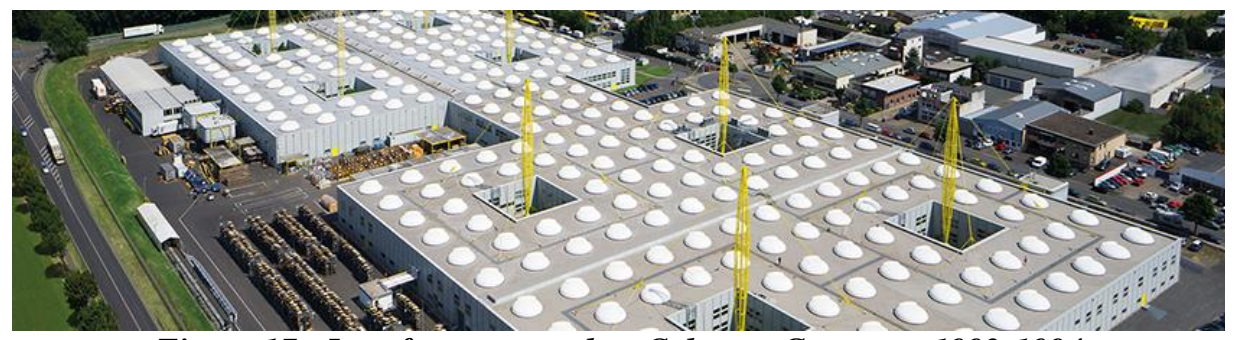

Figure 17 - Igus factory complex, Cologne, Germany, 1992-1994

its corners from the pillars with the help of guys. Cable-stayed roofs of the company restaurant of Audi in Ingolstadt completed in 2000 (architects Ahlheim-Nebe-Schoofs, Darmstadt) can be also related to suspended roof structures with a transverse-and-longitudinal cable-stayed system and with two rows of nine bearing pylons in every row. This stable cable-stayed structure resembles a model shown in Fig. 16 but every pair of bearing pylons is joined by two spatially curved cables.

A cable-stayed roof of multipurpose hall in San Antonio (Texas, USA) completed in 1993 and Renault Distribution Center in Swindon, UK, completed in 1982 and consisted of several typical sections can be also related to the category of suspended multidirectional roof structures with transverse-and-longitudinal cable-stayed system. The Igus factory in Cologne, Germany, designed by Nicholas Grimshaw and Partners [igus.ru/wpck/1681/Factory] contains 8 typical 
sections (Fig. 17). Every roof section is supported by one $86 \mathrm{~m}$ high yellow pylon of unusual form placed in the center of the section. The pylon with the help of the cable-stays holds the roof at 12 points.

Cable-stayed roofs of the WA Basketball Centre in Perth, Australia, completed in 2010 and Multiplex Theater in Saint Herblain, France, can be related also to suspended roof structures with a transverse cable-stayed system and with three and more rows of bearing pylons.

\section{Suspended cable-and-arch roof structures}

A single-span arch-and-cable-stayed structure was used in Cologne, Köln, Germany, in 1996. The Lanxess arena is the Europe's biggest and modern multifunctional arena. In 2013, the Lanxess arena was ranked as the world's third most-frequented multipurpose arena. The arena is spanned by a steel arc of 76 meters high and seats up to 18000 visitors.

The quite new possibilities of suspended cable-stayed structures were discovered by famous architects Norman Foster (Wembley Stadium, London, 2006) and Santiago Calatrava (Stadium «Spyros Luis», Athens, 2004). Their cable-stayed structures represent a separate group of suspended roof structures called pylon arch-and-cable-stayed roof structures, or suspended cableand-arch roof structures, or suspended cable-stay supported arch structures. These names were given to the suspended structures that are supported by cables suspended to a system of arches (pylons). Both pylons and cables (strands), supporting the roof structure, are located above it i.e. the elements of the roof are not placed on the cables directly. Wembley Stadium in London, UK, opened in 2006, is the longest single-span arch-and-cable-stayed structure in the World. The arch holds the northern edge of the section of the stadium roof. The stadium roof can be fully opened for 15 minutes by removing of the mobile panels into the southern stationary roof section. This Stadium takes first place in Europe by seating capacity [14], 90000 visitors simultaneously.

The Durban's Moses Mabhida Stadium built for the FIFA World Cup-2010 (Fig. 18) has become the iconic of Durban City in South Africa. Gerhard le Roux was the leading architect of the project. The tent covering for spectators is suspended to the single arch-pylon with the help of guys organized in a network structure. The rectangular-in-plane roof of the Lufthansa hangar in Hamburg, Germany, is hung up also to the central arc bisected at its both ends.

At present time, a project of the Dolphinarium in Volgograd, Russia, is elaborated in the style of suspended cable-and-arch roof structures (Fig. 19) [28].

Rare and unexpended, the phenomenon of disproportionate collapse usually results to many fatalities. Gerasimidis and Baniotopoulos [29] describe the analysis of a cable-stayed steel roof under the scenario of a cable loss in a cable-stayed bridge-like steel structure with four independent supports on the ground separated by $300 \mathrm{~m}$ in the longitudinal direction and by $145 \mathrm{~m}$ in the transversal one.

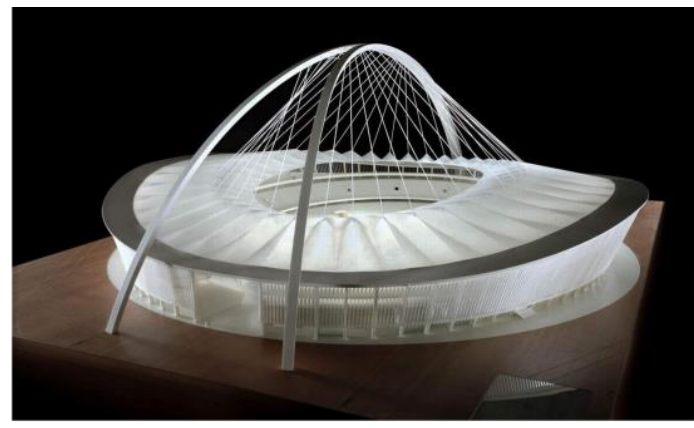

Figure 18. A model of the stadium in Durban (South Africa) [stadiums.at.ua]

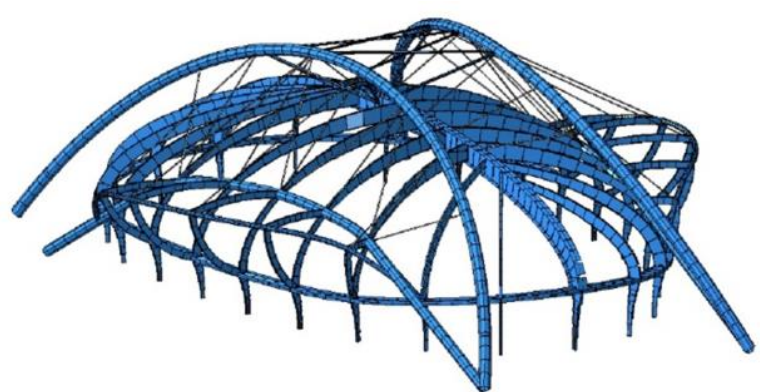

Figure 19. A solid-body model of the design scheme of the Dolphinarium in Volgograd, Russia

\section{Cable-stay supported cantilevers (cable-stayed, cantilevered beam structures)}

Cable-stay supported cantilevers are the stiffening beams which are supported at one end by the guys but the other end rests on the building directly. Cable-stayed cantilever canopy, the free end of which is connected to the bearing wall of the building by several cables, is the simplest 
example of such a single-cantilever system. Links can be made of rods, tubes or cables. Cablestayed cantilever canopy can have large coved area because the second end of the structure is supported by cables which transfer the load from a canopy again at the main building. Displacements of an end of cable-stay supported cantilever can reach a few tens of centimeters, that is why, its overhang is usually taken no more than 40-50 m. Designers can use one-cantilever diagram (Fig. 1, the first line) or two-cantilever diagram (Fig. 1, the $2^{\text {nd }}$ line).

A restaurant in the round tower of the Convention Center on the trade fair ground in Hanover, Germany, is the futuristic building in the form of a cable-stay supported cantilever (Fig. 7).

A good representative of the suspended cantilever roof with overhanging ends is a hangar at the airport of Frankfurt on the Main having $55.65 \mathrm{~m}$ overhang of one cantilever (Fig. 20). The roof structure consists of 16

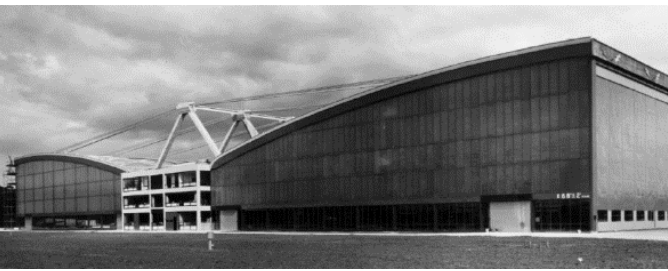

Figure 20 - A hangar at the airport of Frankfurt on the Main, Germany

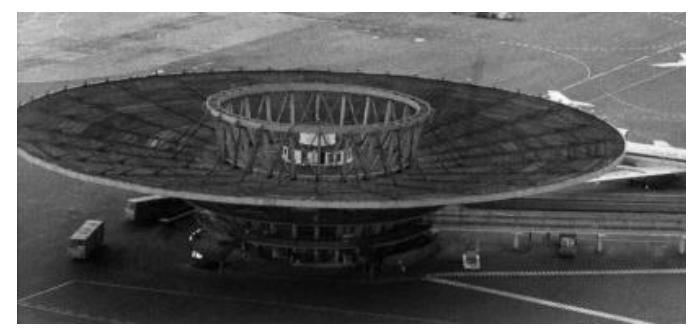

Figure 21 - Gallery for passengers' reception, Sheremetyevo Airport, Moscow, Russia protect guys against corrosion, the tube is filled with cement mortar. Maximum design vertical displacement for the end of the cantilever is $90 \mathrm{~cm}$.

The cable-stayed roof structure of the gallery for passengers' reception at the Sheremetyevo Airport (Fig. 21), erected in 1964, is rather well-known. Some people call this gallery "a wineglass". The circular in plan roof structure consists of steel beams and every beam is supported by four cables with diameter of $59 \mathrm{~mm}$. The carrier cables are attached to a metal ring of the central zone of the building.

A suspended cable-stayed roof structure of the football club "Rennais" erected in 2004 in Rennes, France, can be also added to the group of cable-stay supported cantilevers. This cablestayed roof structure contains the support elements that are grandstands, the rigid cantilevers in the form of broken beams, supported at one end by the guys, and the other ends rest on the stands and are fixed to the ground with the help of guy-wires and anchoring wires. Calculation of the structure was made by the company Egis. A roof of the Gas station in Milano, Italy, is also designed as a cantilever, supported at one end by guys, and with the other end resting on the high pillars braced by guy-wires in the transverse direction [17].

Cable-and-membrane tensile structure of Munich Airport in Germany, Arles Bus Terminal in Arles (Provence-Alpes-Côte d'Arur, France), and the circular in plan roof structure of Pan Am Worldport in New York City, USA (1960-2014) are cable-stay supported cantilevers. The diagram of Arles Bus Terminal in Arles is presented in Fig. 1 (the second line, the third column).

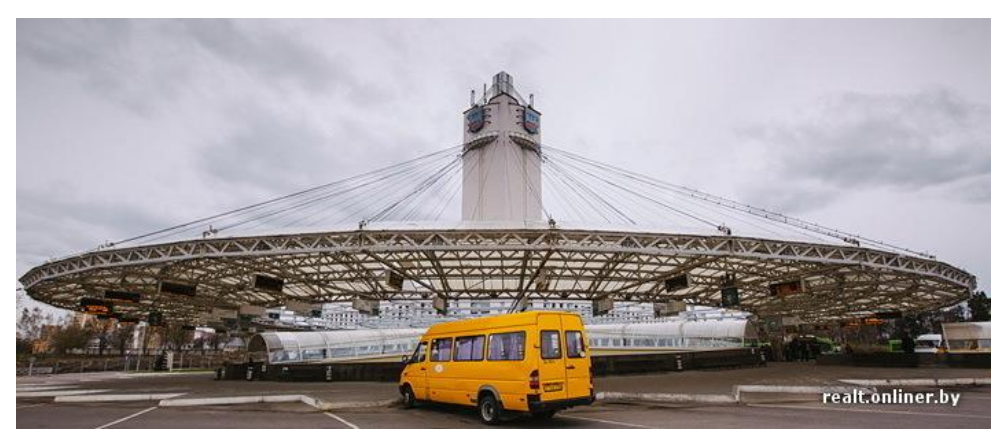

Figure 22 - The shed of a bus station in Minsk, Belorussia 
The bus station in Minsk, Belorussia, built in 1962, represented small one-story bus station. In 1990, it was decided to begin erection of new bus terminal. In summer of 1999, the building of the bus station was completed. New modern building that became the sight of Minsk was erected near the former one-story pavilion (Fig. 22). Architects call the building by the characteristic postmodern object in Byelorussian architecture. Many perceived the Minsk bus station as a futuristic object: big plane circle hanging over the bus parking at thin metal cable-stays. But in November, 2014, this building was demolished and the place was freed for the erection of a skyscraper. The design of the bus station gives an opportunity to include it in «Suspended cable-stayed roof structures with single bearing pylon» also.

The Eugene Bavinger House was completed in 1955 in Norman, Oklahoma, United States. It was designed by architect Bruce Goff in the form of an open helicoid. The house became an attraction. The wall of the house was a 96-foot long spiral, made from 200 tons of local sandstone. A central steel mast was more than 55 feet high. The guys were fixed at one level to this mast but another ends of the tensile guys were fixed at the helicoidal roof. The house had no interior walls; instead there were a series of platforms at different heights. The ground floor was covered with pools and planted areas. This is a significant example of organic architecture, the house was awarded the Twenty-five Year Award from the American Institute of Architects in 1987.

For the determination of the design wind load for a cantilever roof, one can use the results of a work [30]. An article [31] presents numerical simulations for the modelling of seismic impact on the unique cantilever cable-stayed structure with the application of two methods.

\subsection{Cable-stays for stabilization of contour rigid elements of tent membranes}

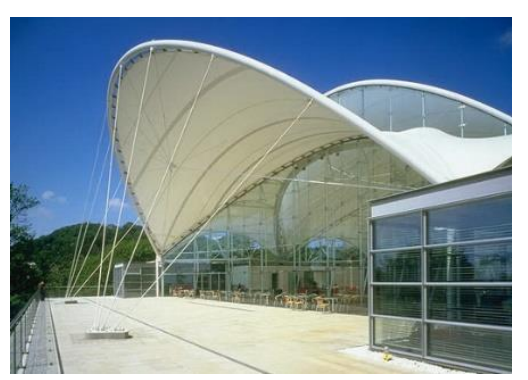

Figure 23 - Tent roof with stabilizing strands

This type of cable-stayed structures is a combined structure which includes wire rope suspension roof structure and incorporates several stabilizing strands (Fig. 23). Structures of this type can be classified both as wire rope suspension roof structures and suspended cable-stayed roof structures. The cables (guy cables) and the tent roof work effectively as a self-balancing structure. Having designed erections of this type, the designers must pay particular attention to anchors i.e. means transforming forces from the basic structure to the ground base.

\subsection{Masted structures with cable-stay elements}

Masted structures with cable-stays ensuring stability of the structures (cable-stayed masts)

A thin vertical mast supported by guy wires is called a guyed mast. One end of the guy is attached to the structure, and the other is anchored to the ground at some distance from the mast or

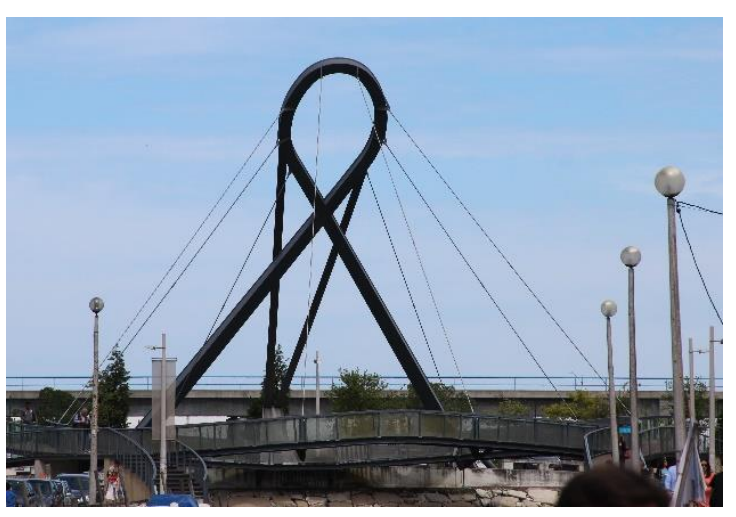

Figure 24 - Sculpture composition in Porto, Portugal tower base. All materials for the stabilizing strands are made of special high-strength steel, the bearing parts of the structure are made, as a rule, of iron and concrete. A mast in the Krasnoyarsk region of Russia can be of good example. The whole height of the tower is 462 meters; cablestayed strands (guy wires) are attached to the mast in 6 points. The sculpture composition in Porto, Portugal, is another interesting example (Fig. 24).

High masts with cable-stayed stabilizing strands can be installed not only on the ground but also on roofs of buildings [9] or on special platform rigidly fixed with the mast.

A manuscript [32] is one of new works 
devoted to non-linear analysis of cable-stayed masts. The dynamic effect for stabilized mast at the different heights is very important, and the main modes of vibration should be considered [33]. Influence of number of cables and inclination angle on the natural frequencies was studied in [34] where the most impotent investigations, devoted to non-linear dynamics of cable-stayed masts, are mentioned too. Finite Element Analysis Ltd insists that the modelling of cable stayed masts is ideally suited to using the LUSAS parametric language. This scripting language allows engineers to automate the modelling and loading of masts having a similar overall structural layout or arrangement [www.lusas.com].

Three accidents of bringing down masts are known. These are the upper section of the 208 $\mathrm{m}$ mast in Felsberg-Berus, Germany, in 2012, a 300 feet upper section of a TV tower in Pennsylvania, USA, in 2007, and a cable-stayed mast of $186 \mathrm{~m}$ high in Russia in 1952.

\section{Masted structures in the form of one-sheet hyperboloid with cable-stays coinciding with rectilinear generatrixes of the surface}

Another kind of cable-stayed structures is known where flexible guys resist only tensile forces. But these structures are put in a separate group, because here guys provide stability of the whole structure, in contrast to suspended cable-stayed structures, but a central pole is the main bearing structure. Sometimes, the unique tower structures have the form of one-sheet hyperboloid of revolution and it is achieved with the help of cables coinciding with the rectilinear generatrixes of the hyperboloid. The structure consists of a central cylindrical pylon with circular platforms placed on it. The outer contour of the platforms coincides with the parallels of one-sheet hyperboloid. Sydney TV Tower, Australia [http://www.enci.ru], and the $108 \mathrm{~m}$ height tower in the port of Kobe, Japan, designed by the company Nikken Sekkei in 1963, belong to this group of cable-stayed structures. Comparing these two towers, having the same form of one-sheet-hyperboloid of revolution, one can notice that they do not resemble each other. In both cases, the talent of the architect is seen. The Sydney TV Tower is a member of the World Federation of Great Towers.

The Killesberg cable-stayed tower, suspended on a central pylon with the height of $40 \mathrm{~m}$ (Fig. 25), was built in Stuttgart Park (Killesbergpark) in 2000. The tower in the form of one-sheet hyperboloid of revolution was designed by Jörg Schlaich. One can climb up on the top of the tower on the spiral staircase of the equal slope attached to the circular plates that are attached to the central pylon.

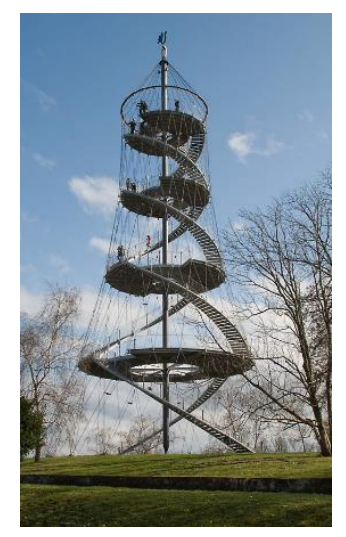

Figure 25 - Masted structure in Stuttgart, Germany

\subsection{Special combined suspended cable-stayed roof structures}

Obviously, not all cable-stayed structures created by architects and engineers can be attributed to one or another type of cable-stayed structures, represented in the classification proposed by the author. For example, the roof over the train platforms in Tilburg (Netherlands), described in [24], with the dimensions of about $46.2 \mathrm{~m}$ by $147 \mathrm{~m}$ consists of 12 hypars. Some corners of these hypars are placed on reinforced concrete supports, while others are supported by guys. Assume the roof structure of the Chunu/Jeonju (Chonju) Stadium in

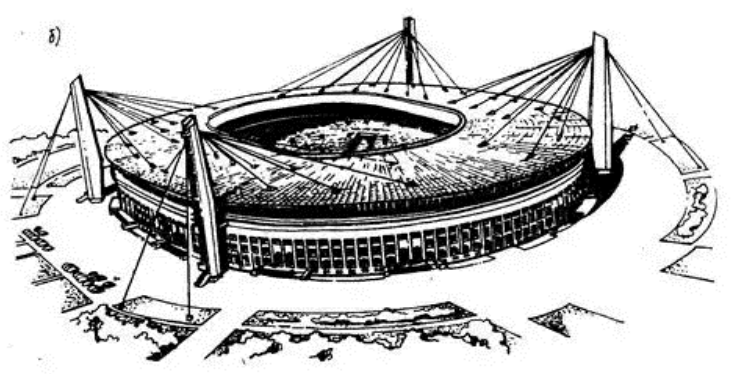

Figure 26 - The cable-stayed system with 4 pylons over the stands of the stadium South Korea with the dimension of $260 \mathrm{~m} \times 160 \mathrm{~m}$ also as an example. The stadium is one of 11 new stadiums being constructed in Korea for the 2002 football World Cup. The roof structure was suspended from four masts (63 meters in height) located in the corners of the stadium [http://www.lusas.com]. Four guys hold the free edge of the 
long section of the stadium and 3 guys hold the free edge of the short section. Additional four guys are stabilizing elements for each mast. The guys with diameters of 65 and $95 \mathrm{~mm}$ were used in this structure. The cable-stayed roof structures over the stands of the stadium, proposed by V.V. Handji and I.V. Lisitsyn (Fig. 26) [5], can be also attributed to this group of suspended cable-stayed roof structures.

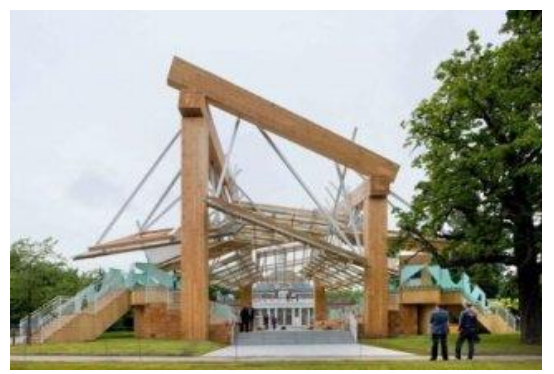

Figure 27 - Serpentine Gallery Pavilion, London, 2002

Kazakhstan site [update.kz] called Serpentine Pavilion in London, UK, as one of the impressible erection of the last ten years. This erection is a special combined suspended cablestayed structure (Fig. 27) with disorderly arrangement of rigid elements and guys.

In 2002, the International Association for Bridge and Structural Engineering awarded a prize recognizing the unique structure of the Stade de France (Fig. 28) in Saint-Denis, north of Paris, France, commenting that the Stade de France exhibited "a construction of an attractive open architecture of the city, with an elegance and natural lightness". Here, one row of support masts arranged in an ellipse carries the roof. So, this structure can be called also a suspended cable-and-rod roof structure with bearing pillars placed at one row.

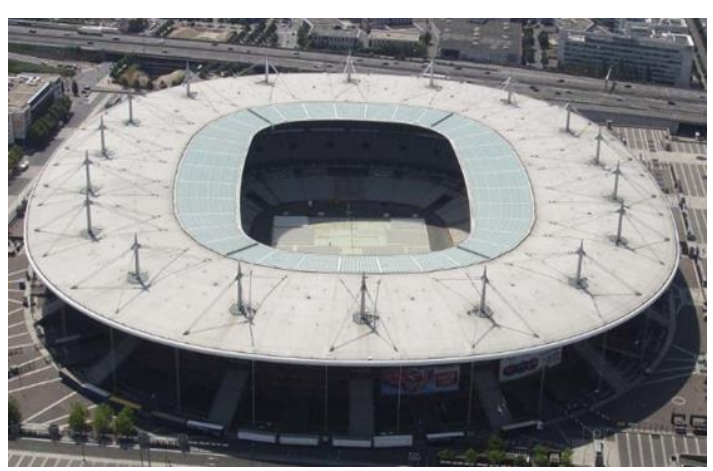

Figure 28 - The Stade de France, Saint-Denis, France

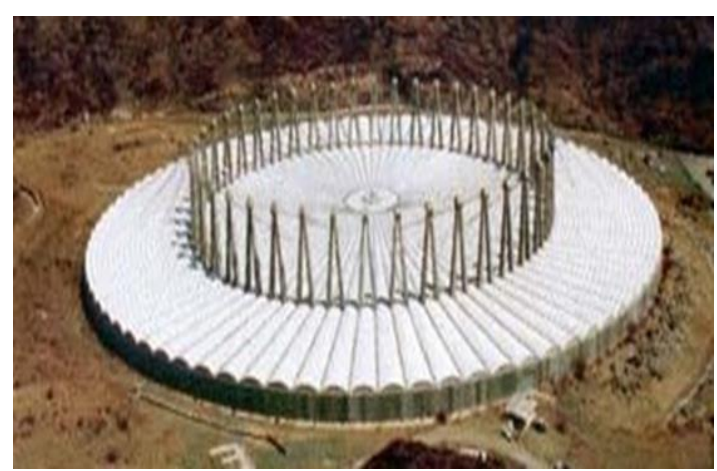

Figure 29 - Reservoir near Al-Makkah, Saudi Arabia

BC Place Stadium in Vancouver, Canada, completed in 2011; the $330 \mathrm{~m}$ in diameter cover for approximately one million water cubic meters circular bulk storage reservoir near Al-Makkah in Saudi Arabia, Fig. 29; Welsh national stadium in Cardiff (Wales), the third largest stadium in Britain; Bangkok Futsal Arena in Bangkok, Thailand, with the dimensions of $132 \times 116 \times 25$ meters and with four 56-meter pylons at each corner; Manchester City Stadium (the Etihad stadium) in UK, opened in 2002, and received much praise and many accolades, including an award from the Royal Institute of British Architects in 2004 for its innovative inclusive building design and a special award in 2003 from the Institution of Structural Engineers for its unique structural design; National Exhibition Centre in Birmingham, UK, opened in 1976; Sydney Super Dome in Australia, opened in 1999; "National Stadium" in Warsaw, Poland [35], with expressive multifunctional arena with a retractable inner roof above the field, opened in 2012, and a fabricated tensioned cable structure of the Millennium Dome can be also related to special combined suspended cable-stayed roof structures. The rectangular form of the RheinEnergieStadion with the four steel towers at the corners has become one of the symbols of the Cologne city in Germany. It was built to replace Cologne's old Müngersdorfer Stadion with the perspective of the city being one of the host cities of the 2006 World Cup and was opened in 2004. It is also attributed to a group of special combined suspended cable-stayed roof structures.

Construction of the Toyota Stadium with transforming segments of the roof was far from obvious and not welcome by all people in Toyota, Japan. The Stadium was one of the venues of the 2002 FIFA Club World Cup. Two stationary parts of the roof are nonmetal mesh shells hung up with the help of cable-stays (140-200 mm in diameter) to four masts of $90 \mathrm{~m}$ high [36]. The main 
dimensions of the closed roof of the stadium are $195 \mathrm{~m} \times 92 \mathrm{~m}$. This unusual erection is also reckoned among special combined suspended cable-stayed roof structures.

With the help of these structures, it is possible to create impressed geometric forms and, at the same time, effectively to cover large areas without intermediate supports. Interesting examples of the application of combined suspended arch-and-cable structures in the Russian Federation are given in the paper of D.B. Kiselev [37]. In Russia, interest in the cable-stayed roof structures particularly intensified due to the FIFA decision to hold a world champion-ship for football in the Russian Federation in 2018. Modern roof structures of

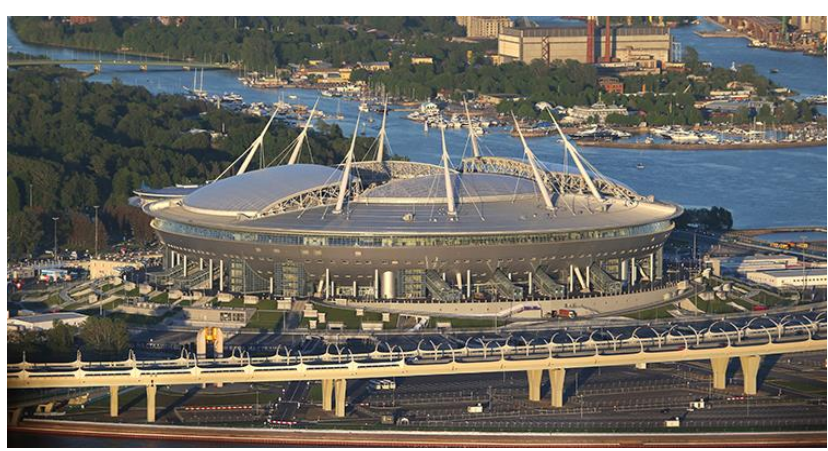

Figure 30 - The stadium "Zenit Arena", Saint Petersburg, Russia (photo by P. Kovalev) sports arenas were built mainly with application of suspended cable-stayed and wire rope suspension structures. For example, a stadium "Zenit Arena" with the eight inclined pylons was erected in Saint Petersburg (Fig. 30), a stadium "Rostov Arena" was erected in Rostov-upon-Don.

The first cable-stayed roof structure for sport arena in Russia was built over Lokomotiv Stadium in Moscow in 2002 [38]. The design was devised by GUP MNIIP jointly with GUP TsNIISK. The $\wedge$-shaped inclined reinforced concrete pillars were placed in four corners of the stadium. The main dimensions of the oval roof of the stadium are $205.67 \times 157.35 \mathrm{~m}$. The tops of all four pillars were united by the main stay suspension cables with a $140 \mathrm{~mm}$ diameter. The pair cable hangers are of $50 \mathrm{~mm}$ in diameter (Fig. 16). They hold the light-transparent covering of $33 \mathrm{~m}$ wide. In 2017, the Lokomotiv Stadium was modernized.

\subsection{Suspended bridges}

Suspended bridges are divided into two main groups (Fig. 31). An element $A B C$ in the bridges of the first group is made of separate units, combined in the chain (Fig. 31, $a$ ). The $A B C$ chain together with anchoring guy-wires $A D, E C$, and pylons $A a, C c$ bears the entire load. Today, the $A B C$ element is made of cables, but the name "Chain Bridge" of the bridge group was retained unchanged (Fig. 32). Chain bridges were built in India and China in the first century already.

Bridges of the second group (Fig. 31, b) call cable-stayed bridges. Here, braces and chords resist a load. Cable-stayed suspension bridges are divided into 3 groups: cable-stayed statically determinate trusses, statically indeterminate prestressed trusses without stiffening girders, and statically indeterminate cable-stayed trusses with stiffening girders (Fig. 31, b). Additional information on classification of suspension bridges, their design considerations, and methods of analysis can be taken in [39, 40, and 41]. In this section, the existence of such cable-stayed structures as "suspended bridges" is indicated only.

At present, the world's highest suspension bridge is a bridge connecting Vladivostok with Russian Island. The top of its main pillars is 327

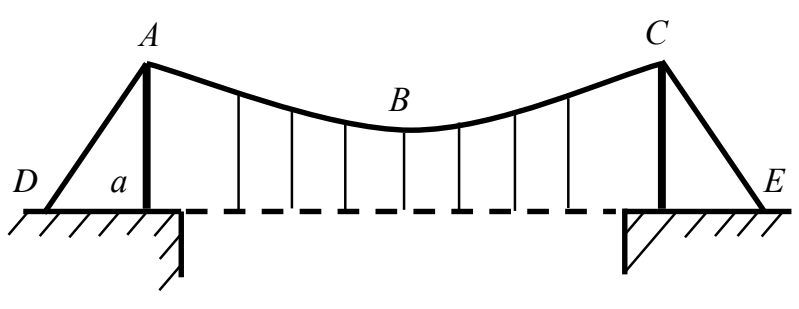

$a$

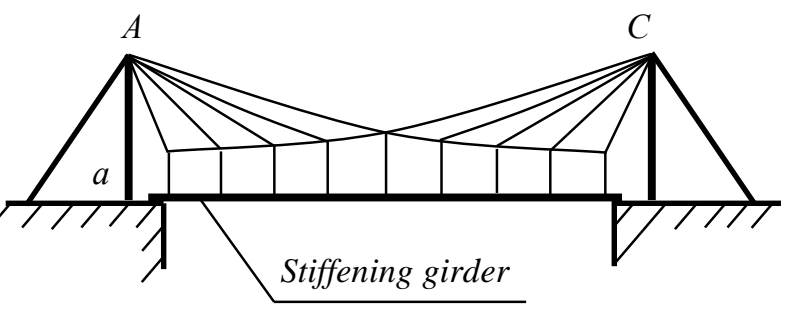

$b$

Figure 31 - Two types of suspended bridges $\mathrm{m}$ away from the see surface. The longest central span is $1104 \mathrm{~m}$. A common length of tension cables-guys is almost $55 \mathrm{~km}$ (Fig. 33). 


\section{Brief information on strength analysis of cable-stayed structures}

Information about cable-stayed structures would be not full if architect does not know the basis of strength analysis of these structures. Due to different applications, the analysis of cablestayed structures has been object of several investigations in the last years. Systematized initial information on static analysis of cable-and-rod combined systems is given in [42]. By the way, A.V.

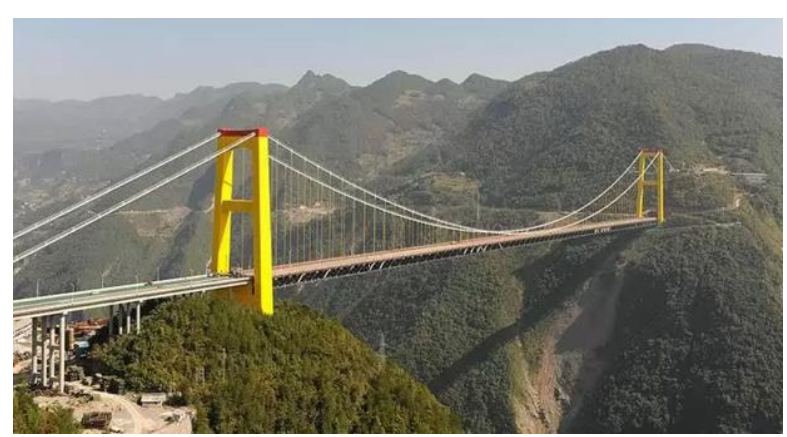

Figure 32 - Siduhe River Bridge, 2009. The length of the main span is $900 \mathrm{~m}$, the distance the road from the bottom of the canyon is $496 \mathrm{~m}$

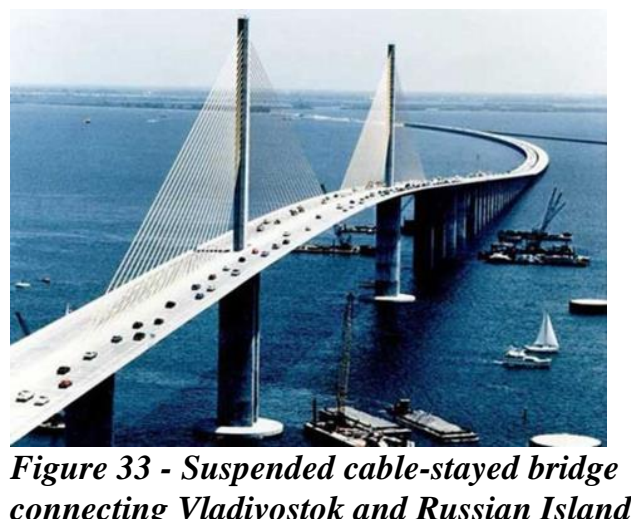

connecting Vladivostok and Russian Island

Perelmuter introduces the term "quasi-invariability of cable-stayed system". It means that a system, derived from a cable-stayed system by replacing of all cables by rods that are able to resist compression, becomes geometrically invariable.

There are enough numbers of structural engineers who can give satisfactory support to architects [26, 30-34, 42, 43-49]. In a paper [46], a hybrid micro-genetic algorithm is developed to detect tension forces of cable-stayed structures subjected to impact loads. For the numerical analysis, a perfected finite element computer program was used, which permitted to avoid premature convergence due to incorrect initial values. Static analysis of a cable-stayed structure, subjected to in plane loading with consideration of geometrical nonlinearity of cables as well as shear deformation effect in the bending element, is presented in a paper [48]. It allows to determine displacements and internal forces of structure without too much hypothesis as in traditional methods. The influence of temperature variations on the mechanical behavior of cables, used in cable-stayed structures, is investigated in [49].

\section{Results and discussions}

In 1834, steel wire ropes were invented. Steel wire rope is a new constructive element that found wide application in construction due to its strength, small mass, flexibility, and durability. First, steel cables were used as bearing elements of suspended bridges and after that they received wide spread in large-span suspended roof structures.

Suspended cable-stayed roof structures inspire engineers over the years. They have application in a variety of wide span structures like exhibition halls, stadiums, sports halls, swimming pools, warehouses, factories, hangers, and so on. However, the cable-stayed systems are still fairly new type of roof structures. Today, cable-stayed structures are considered as innovative design considerations. In addition, several computer programs simplifying design of cable-stayed structures were created for architects [50]. Ciro Cuono P.E. and Michael Wyetzner in their work "Cables in Structures" have written "Exposed and visible, cable-stayed structures are the ultimate honest expression of structure and thus provide a wide variety of distinct architectural forms".

But till present time, designers do not have a finished classification of cable-stayed structures. Often they confuse various groups and sub-groups of these erections.

In this paper, a new classification is presented. It differs from the classifications proposed by M. Majowiecki [2], A.A. Zagorkov [3], L.A. Kloiber et al [4], J.B. Harris and Pui-K Li Kevin [11], E.Yu. Ageeva and A.I. Spiridonova [14], and G. Quelle Iago [55]. 
A list of notable cable-stayed structures, mentioned in the paper, is provided in the Table. In this table, cable-stayed structures are grouped under new classification. Having this table, everyone can make an analysis on application of cable-stayed structures for buildings of diverse purposes, on architects working in this area, on countries using this type of erections, and so on. A list of the cable-stayed structures built before 1995 is given in a publication [11]. This list and a list of the notable cable-stayed structures presented in the Table well add each other. W. Schueller in his work "The Cable in Structures Including SAP2000" [51] also presents interesting examples of simply suspended structures and suspended cable-and-arch-supported roof structures.

Table - Notable cable-stayed structures described in the manuscript

\begin{tabular}{|c|c|c|c|c|c|}
\hline Structure & Location & Country & Architects, designers & Opened in & Presented in \\
\hline \multicolumn{5}{|c|}{ 1) Cable-stayed roof structures (straight tensioned cable roof structures): } & \\
\hline \multicolumn{5}{|c|}{ Suspended cable-stayed roof structures supporting tent (fabric) membranes in particular points: } & \\
\hline $\begin{array}{l}\text { The Lawn Tennis Association's } \\
\text { National Tennis Centre }\end{array}$ & London & UK & Hopkins Architects & 2008 & Fig. 2 \\
\hline The Olympic stadium & Munich & Germany & Otto Frei, G. Behnisch & 1972 & [9] \\
\hline Beaufort Ice Skating Rink & Beaufort & Luxembourg & Architekten \& Ingenieure & 2011 & Fig. 3 \\
\hline $\begin{array}{l}\text { NSC Kuala Lumpur roof over } \\
\text { swimming stadium }\end{array}$ & Kuala Lumpur & Malaysia & $\begin{array}{l}\text { Schlaich Bergermann } \\
\text { Partner }\end{array}$ & 1997 & www.sbp.de \\
\hline Grande Arche of La Défence & Paris & France & J. Otto Spreckelsen & 1989 & [13] \\
\hline \multicolumn{5}{|c|}{ Suspended cable-stayed structures with single bearing pylon } & \\
\hline Pavilions of flowers & Kassel & Germany & & 1955 & Fig. 4 \\
\hline Ontario Place Pods & Toronto & Canada & Ed Zeidler & $1971-2011$ & zeidler.com/ \\
\hline Ice Palace "Krylatskoe" & Moscow & Russia & M. Ya. Livshin & 2006 & [14], [38] \\
\hline $\begin{array}{l}\text { Ré Island Toll Gate, Poiton- } \\
\text { Charente }\end{array}$ & La Rochelle & France & $\begin{array}{l}\text { CABINET SEPRA + } \\
\text { BET SIT }\end{array}$ & 1988 & \\
\hline Olympic Stadium & Montréal & Canada & Roger Taillibert & 1976 & Fig. 6 \\
\hline Convention Center & Hannover & Germany & $\begin{array}{l}\text { H. Storch \& W. Ehlers } \\
\text { (SEP) Arch }\end{array}$ & 1989 & Fig. 7,[51] \\
\hline Civil aircraft museum (a project) & Sestoretzk & Russia & A. Kuz'mina & 2014 & Fig. 8 \\
\hline Juventus Stadium & Turin & Italy & H. Suarez, G.Zavanella & 2011 & StadiumDB.com \\
\hline \multicolumn{5}{|c|}{ Suspended cable-and-rod roof structures with bearing pillars placed at one or several rows } & \\
\hline Italtubi warehouse & Rome & Italy & S. Musmeci & 1963-67 & [17] \\
\hline The UK Pavilion at EXPO-70 & Osaka & Japan & Ph. Powell and H. Moya & 1970 & [9] \\
\hline But-Pôle Atlantis & Saint Herblain & France & & & [18] \\
\hline The shed over the petrol station & Nizhnevartovsk & Russia & ARHIKOM & 2004 & Fig. 9 \\
\hline The PA Technology Center & Princeton & USA & $\begin{array}{l}\text { Richard Rogers, Ove } \\
\text { Arup Struct. Eng. }\end{array}$ & $\begin{array}{l}1982- \\
1984 \\
\end{array}$ & [9], [22] \\
\hline Atatürk Stadium & Istanbul & Turkey & A. Zublena, M. Macary & 2002 & [19] \\
\hline Yishun Stadium & Singapore & Singapore & $\begin{array}{l}\text { WY Steel Construction } \\
\text { Pte Ltd }\end{array}$ & 1992 & [20] \\
\hline Suspended green roof in Lyons & Leone & France & Jourda and Perraudin & 1992 & [9] \\
\hline Green roof Service LLC & Stuttgart & Germany & Jörg Breuning & 1980 & Fig.10 \\
\hline Bayfront Convention Center & Erie & USA & Barton Malow Co. & 2007 & {$[18]$} \\
\hline $\begin{array}{l}\text { Champratel Bus and Tramway } \\
\text { Depot }\end{array}$ & $\begin{array}{l}\text { Clermont- } \\
\text { Ferrand }\end{array}$ & France & & & [18] \\
\hline Bus stop & Milan & Italy & & 1949 & [17] \\
\hline $\begin{array}{l}\text { The Gerald Rather Athletics } \\
\text { Center of the University of } \\
\text { Chicago }\end{array}$ & Chicago & USA & $\begin{array}{l}\text { Cesar Pelli \& Associates } \\
\text { teamed with OWP/P }\end{array}$ & 2003 & Fig.11, [4] \\
\hline Railway station & Nanjing & China & & 1968 & Fig.12 \\
\hline The Eastleigh Tennis Center & Southampton & UK & $\begin{array}{l}\text { Euan Borland Associates } \\
\text { and Buro Happold } \\
\text { Consulting Engineers } \\
\end{array}$ & after 1994 & {$[8],[23]$} \\
\hline
\end{tabular}


Строительство и реконструкция

\begin{tabular}{|c|c|c|c|c|c|}
\hline $\begin{array}{l}\text { Olympic stadium (Ice Hockey } \\
\text { Rink) }\end{array}$ & Squaw Valley & USA & Corlett \& Spackman & 1960 & {$[24]$} \\
\hline Pescia flower market & Pescia & Italy & I. Savioli at al & 1981 & [17] \\
\hline The company restaurant of Audi & Ingolstadt & Germany & $\begin{array}{l}\text { Ahlheim-Nebe-Schoofs, } \\
\text { Darmstadt }\end{array}$ & 2000 & www.sbp.de \\
\hline The main entrance to EXPO-89 & Yokohama & Japan & G.K. Sekkei Associates & 1989 & {$[55]$} \\
\hline Eastville Tesco & Bristol & UK & D.Daw Architects & $1984-86$ & {$[11]$} \\
\hline $\begin{array}{l}\text { Conference Center in Smart } \\
\text { Village }\end{array}$ & Giza & Egypt & & 2002 & {$[56]$} \\
\hline Kaliningrad Stadium & Kaliningrad & Russia & Crocus International & 2018 & StadiumDB.com \\
\hline A paper factory & Mantua & Italy & P.L. Nervi & 1963 & {$[24]$} \\
\hline Oxford Ice Rink & Oxford & UK & N. Grimshaw \& Partners & 1984 & [57] \\
\hline Fleetguard factory & Quimper & France & $\begin{array}{l}\text { Richard Rogers, Ove } \\
\text { Arup Struct. Eng. }\end{array}$ & 1981 & Fig. 15 \\
\hline A Igus factory complex & Cologne & Germany & N. Grimshaw \& Partners. & 1994 & Fig. 17 \\
\hline Multipurpose hall & San Antonio & USA & J.A. Martin Ass. and others & 1993 & \\
\hline Bendat Basketball Centre & Perth & Australia & Jackson Arch. and others & $01.24,2010$ & en.wikipedia.org \\
\hline Multiplex Theater & Saint Herblain & France & Richard Rogers & 1987 & \\
\hline INMOS microprocessor factory & Newport & UK & $\begin{array}{l}\text { R. Rogers \& Partners, An- } \\
\text { thony. Hunt Struct. Eng. }\end{array}$ & $\begin{array}{l}1980- \\
1982\end{array}$ & {$[25]$} \\
\hline Renault Distribution Center & Swindon & UK & Norman Foster & 1982 & [51] \\
\hline Railway Station & Tilburg & Holland & Koen van der Gaast Arch. & 1965 & {$[24],[51]$} \\
\hline Ocean Terminal & Piraeus & Greece & J. Liapis, E. Skroubelous & 1972 & {$[11]$} \\
\hline The Green Theatre (a project) & Edinburg & UK & Ch. MacIntosh & 1853 & [11] \\
\hline Sport hall (a project) & Zagreb & Croatia & T.J. MacGinley, M. Đuran & 2002 & {$[26]$} \\
\hline Altos de la Vanega Metro Station & Zulia & Venezuela & & 2006 & {$[18]$} \\
\hline \multicolumn{6}{|c|}{ Suspended cable-and-arch roof structures } \\
\hline The Lanxess arena & Cologne & Germany & Peter Böhm Architekten & 1998 & {$[51]$} \\
\hline Wembley Stadium & London & UK & Norman Foster & 2006 & [9], [14] \\
\hline Stadium «Spyros Luis» & Athens & Greece & Santiago Calatrava & 2004 & [9] \\
\hline $\begin{array}{l}\text { The Durban's Moses Mabhida } \\
\text { Stadium }\end{array}$ & Durban & $\begin{array}{l}\text { South } \\
\text { Africa }\end{array}$ & Gerhard le Roux & 2010 & [9], [52] \\
\hline The Lufthansa hangar 7 & Hamburg & Germany & van Gerkan Marg Arch. & 2009 & $\begin{array}{l}\text { www.lufthansa- } \\
\text { technik.com }\end{array}$ \\
\hline Dolphinarium (a project) & Volgograd & Russia & $\begin{array}{l}\text { Ishmametov R.H., } \\
\text { Galitzkaya E.M. } \\
\end{array}$ & 2018 & Fig. 19 \\
\hline \multicolumn{6}{|c|}{ Cable-stay supported cantilevers (cable-stayed, cantilevered beam structures } \\
\hline Tower restaurant, Convention Center & Hanover & Germany & & 1989 & Fig. 7 \\
\hline Munich Airport & Munich & Germany & Günter Büschl Arch & 1992 & [41] \\
\hline Roof structure of the Gas station & Milan & Italy & unknown designer [13] & & [17] \\
\hline $\begin{array}{l}\text { A hangar at the airport of } \\
\text { Frankfurt on the Main }\end{array}$ & $\begin{array}{l}\text { Frankfurt on } \\
\text { the Main }\end{array}$ & Germany & $\begin{array}{l}\text { ABB Architects, } \\
\text { Dyckerhoff and Widmann }\end{array}$ & 1972 & Fig. 20 \\
\hline $\begin{array}{l}\text { Gallery for passengers' reception, } \\
\text { Sheremetyevo Airport }\end{array}$ & Moscow & Russia & $\begin{array}{l}\text { G.A. El'kin, G.V. } \\
\text { Kryukov }\end{array}$ & $\begin{array}{l}1964- \\
2018\end{array}$ & Fig. 21 \\
\hline Bus station "Moskovskiy" & Minsk & Belorussia & $\begin{array}{l}\text { N.Naumov, Yu.Rushev, } \\
\text { L. Volchetskiy }\end{array}$ & $\begin{array}{l}1999- \\
2014\end{array}$ & Fig. 22 \\
\hline The football club "Rennais" & Rennes & France & Atelier Bruno Gaudin & 2004 & [9] \\
\hline Arles Bus Terminal & Arles & France & & & {$[18]$} \\
\hline Pan Am Worldport (Terminal 3) & New York & USA & $\begin{array}{l}\text { Ives, Turano \& Gardner } \\
\text { Associated Architects and } \\
\text { Walther Prokosh }\end{array}$ & $\begin{array}{l}1960- \\
2014\end{array}$ & $\begin{array}{l}\text { https://www.we } \\
\text { buildvalue.com }\end{array}$ \\
\hline The Eugene Bavinger House & $\begin{array}{l}\text { Norman, } \\
\text { Oklahoma }\end{array}$ & USA & Bruce Goff & $\begin{array}{l}1950- \\
2016\end{array}$ & $\begin{array}{l}\text { https://en.wikip } \\
\text { edia.org }\end{array}$ \\
\hline \multicolumn{5}{|c|}{ 2) Cable-stays for stabilization of contour rigid elements of tent membranes } & Fig. 23 \\
\hline \multicolumn{6}{|c|}{ 3) Masted structures with cable-stay elements } \\
\hline \multicolumn{5}{|c|}{ Masted structures with cable-stays ensuring stability of the structures (cable-stayed masts) } & \\
\hline
\end{tabular}


Теория инженерных сооружений. Строительные конструкции

\begin{tabular}{|c|c|c|c|c|c|}
\hline $\begin{array}{l}\text { The } 462 \mathrm{~m} \text { height mast (Chayka- } \\
\text { mast) }\end{array}$ & Dudinka & Russia & E.S. Poltorak & 1980 & en.wikipedia.org \\
\hline The sculpture composition & Porto & Portugal & & & Fig. 24 \\
\hline \multicolumn{6}{|c|}{$\begin{array}{c}\text { Masted structures in the form of one-sheet hyperboloid with cable-stays coinciding with } \\
\text { rectilinear generatrixes of the surface }\end{array}$} \\
\hline Sydney TV Tower & Sydney & Australia & Donald Crone and Ass. & 1981 & [9] \\
\hline Tower in the port of Kobe & Kobe & Japan & $\begin{array}{l}\text { the company Nikken } \\
\text { Sekkei }\end{array}$ & 1963 & [9] \\
\hline The Killesberg cable-stayed tower & Stuttgart & Germany & Jörg Schlaich & 2000 & Fig. 25 \\
\hline \multicolumn{6}{|c|}{ 4) Special combined suspended cable-stayed roof structures } \\
\hline The train platforms & Tilburg & Netherlands & Koen van der Gaast Arch & 1965 & {$[24],[33]$} \\
\hline Chunu/Jeonju Stadium & Jeonju & South Korea & $\begin{array}{l}\text { Pos A.C. Arch, CS Struct. } \\
\text { Eng }\end{array}$ & 2002 & [9], [53] \\
\hline Serpentine Gallery Pavilion 2008 & London & UK & Frank Gehry & 2008 & Fig. 27 \\
\hline BC Place Stadium & Vancouver & Canada & $\begin{array}{l}\text { Studio Phillips Barratt, } \\
\text { Ltd, and others }\end{array}$ & 2011 & StadiumDB.com \\
\hline Mina water reservoir & Al-Makkah & Saudi Arabia & Muna Project & Aug. 1986 & Fig.29 \\
\hline $\begin{array}{l}\text { Principality Stadium (Welsh } \\
\text { National Stadium in Cardiff) }\end{array}$ & Wales & UK & $\begin{array}{l}\text { Bligh Lobb Sports } \\
\text { Architecture, W.S. Atkins }\end{array}$ & 1999 & StadiumDB.com \\
\hline Bangkok Futsal Arena & Bangkok & Thailand & $\begin{array}{l}\text { King Mongkut's Univ. of } \\
\text { Technology Thonburi }\end{array}$ & 2015 & $\begin{array}{l}\text { https://en.wikip } \\
\text { edia.org }\end{array}$ \\
\hline Manchester City Stadium & Manchester & UK & ArupSport & 2002 & [51] \\
\hline National Exhibition Centre & Birmingham & UK & Ed. Mills, S. Harris & 1976 & en.wikipedia.org \\
\hline Sydney Super Dome & Sydney & Australia & $\begin{array}{l}\text { Abigroup Ltd and } \\
\text { Obayashi Corporation }\end{array}$ & 1999 & $\begin{array}{l}\text { https://en.wikip } \\
\text { edia.org }\end{array}$ \\
\hline The Stade de France & Saint-Denis & France & $\begin{array}{l}\text { M. Macary, A. Zublena, } \\
\text { M. Regembal, Cl. } \\
\text { Constantini }\end{array}$ & 1998 & Fig. 28 \\
\hline The Millennium Dome & London & UK & R. Rogers & 1.1 .2000 & {$[1]$} \\
\hline RheinEnergieStadion & Cologne & Germany & Gerkan, Marg und Partner & 1.31 .2004 & StadiumDB.com \\
\hline SCHARRena $(76 \mathrm{~m} \times 38 \mathrm{~m} \times 11,5 \mathrm{~m})$ & Stuttgart & Germany & ASP Architekten Arat & 2011 & www.sbp.de \\
\hline National Stadium & Warsaw & Poland & GMP Architekten & 2012 & [35] \\
\hline Toyota Stadium & Toyota & Japan & $\begin{array}{l}\text { Kisho Kurokawa } \\
\text { Architect \& Associates }\end{array}$ & 07.21 .2001 & [36], [38] \\
\hline Lokomotiv Stadium (RZD Arena) & Moscow & Russia & A. Bokov, D. Bush et al & 2002 & [38] \\
\hline $\begin{array}{l}\text { Zenit Arena (St. Petersburg } \\
\text { Football Stadium) }\end{array}$ & S. Petersburg & Russia & $\begin{array}{l}\text { Kisho Kurokawa } \\
\text { architects \& associates }\end{array}$ & 2018 & Fig. 30, [54] \\
\hline A stadium "Rostov Arena" & Rostov-on-Don & Russia & $\begin{array}{l}\text { "Sport-Engineering", } \\
\text { Inteks, TzNIIPromzdaniy }\end{array}$ & 2018 & {$[58]$} \\
\hline Stadium (a project) & & Russia & V.V. Handji, I.V. Lisitsyn & 1991 & Fig. 26 \\
\hline Alamodome & San Antonio & USA & W.E. Simpson Com. et al. & 5.15 .1993 & {$[18]$} \\
\hline \multicolumn{6}{|c|}{ Cable-stayed erections sorted simultaneously into several categories } \\
\hline Grand Bigo (Columbus 1992) & Genova & Italy & $\begin{array}{l}\text { Renzo Piano with Ove } \\
\text { Arup and Partners }\end{array}$ & 1992 & {$[18]$} \\
\hline Düsseldorf Airport Railroad Station & Düsseldorf & Germany & & 2000 & [18] \\
\hline
\end{tabular}

Some cable-stayed erections can be sorted into several categories simultaneously. For example, the Grand Bigo in Columbus, opened in 1992, made of eight masts contains also a tent roof hung up by cables from the four steel tubular arches. So, this hybrid can be related to cablestayed masts, or to suspended cable-and-arch structures, or to suspended cable-stayed roof structures supporting tent membranes in particular points. Analogically, combined suspended cablestayed roof structures of Düsseldorf Airport Railroad Station in Germany, opened in 2000, with four pillars can be also sorted into several categories simultaneously.

A unique cantilever cable-stayed structure, described in [31], is used by some designers for public multifunctional buildings. This structure contains open cables, but they are hidden in a body of the building. Although this solution is not yet widely known, there are few existing models 
already. One of them is the Cosmopolitan skyscraper, inaugurated in December 2013 in Warsaw, Poland. This atypical cantilever cable-stayed structure now is out of the classification presented at the beginning of the paper.

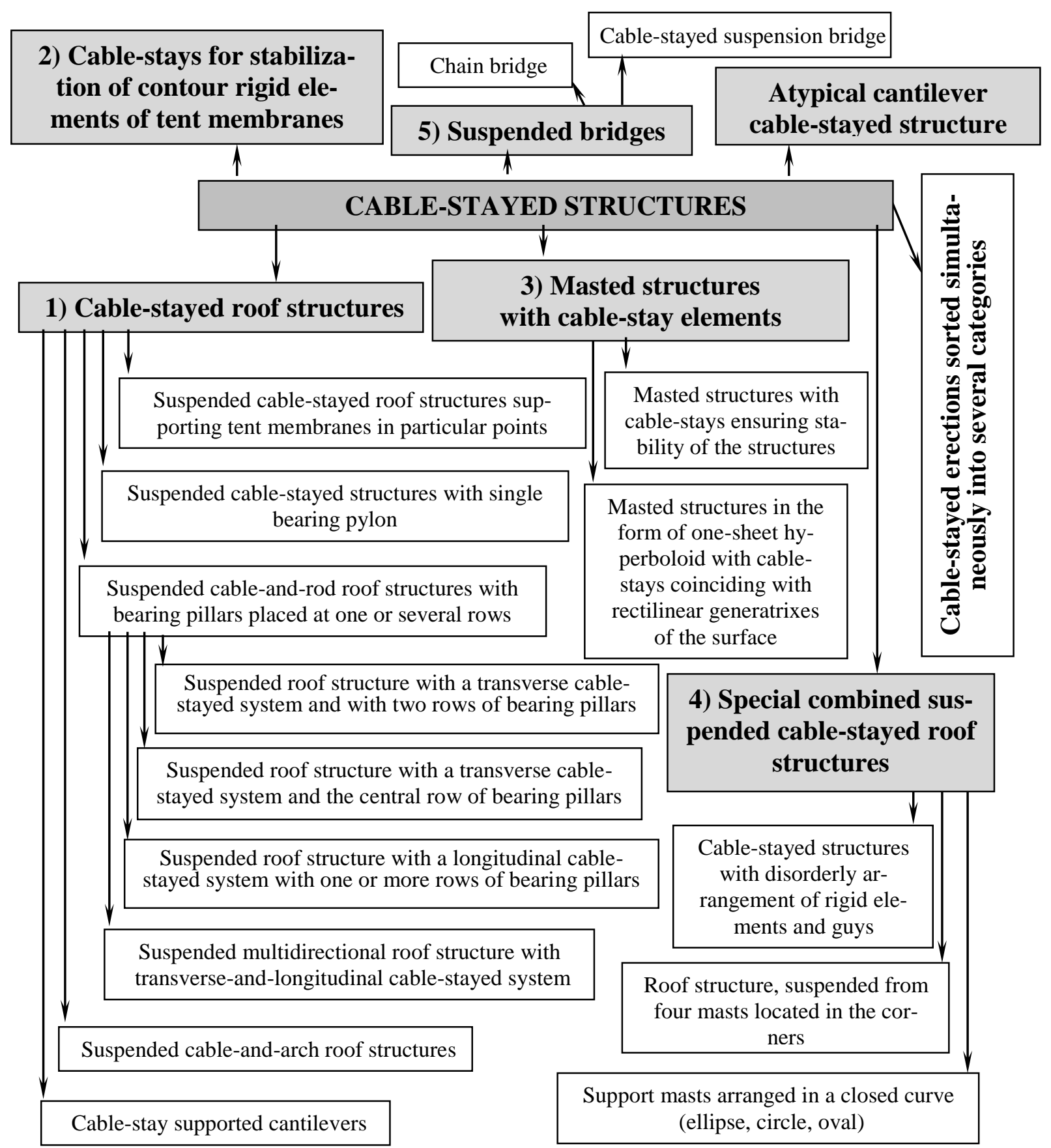

Figure 34 - A broadened classification of cable-stayed structures

Sometimes, it is more convenient to use the representation of the classification in the form shown in Fig. 34.

About one hundred cable-stayed erections are examined in a paper but in the World, we have much more of them and it is impossible to point out the references dealing with question. New classification of erected buildings and the illustration of every class and subclass of cable-stayed structures by real examples is an aim of this paper. All variety of incarnated constructive solutions and sketches, projects, models, and offers suggested for realization is presented. 


\section{CONCLUSION}

Having summarized the information presented in the paper, one can draw the following conclusions.

1. For the first time, a classification of cable-stayed structures was compiled with due regard for structural model, lay-out diagram of pillars, cables, and so on.

2 . For the first time, every group and sub-group of cable-stayed structures are illustrated by the most notable erections.

3. The cable-suspended structures differ from the cable-stayed suspension systems because the covering elements in them are placed directly on the wire ropes or on the wire rope net.

4. Besides suspended cable-stayed systems, cable-stayed structures include in themselves also the structures containing cables as the stabilizing elements or creating geometrical image of the erection.

5. Ten not old cable-stayed buildings or thereabouts were demolished and the place was freed for the other erections. It would be interesting to study the main reasons of these decisions.

6. According to the examples demonstrated, there are good perspectives for the construction of all types of cable-stayed structures included in the classification, proposed by the author.

7. Study of the prerequisites of the structural solutions in building, the history of the development and perfecting of building technologies of erection of cable-stayed structures will permit to generalize the experience accumulated by designers and to develop new fundamental solutions. Otherwise, architects and designers will be repeating the achieved solutions in building and architecture.

\section{Acknowledgments}

The publication was prepared with the support of the RUDN University Program "5-100".

\section{REFERENCES}

1 R. Bradshaw, D. Campbell, M. Gargari, A. Mirmiran, P. Tripeny. Special structures: Past, present, and future. Journal of Structural Engineering. 2002. Pp. 691-709.

2 M. Majowiecki. Tensostructture: progetto e verifica. CREA edition. 1985.

3 A.A. Zagorkov. Tectonics of vertical abutment. AMIT. 2012. 3 (20). 19 p.

4 L.A. Kloiber, D.E. Eckmann, Th.R. Meyer, St.J. Hautzinger. Design considerations in cable-stayed roof structures, North American Steel Construction: Conference: Modern Steel Construction (March 2004). Pp. 75-84.

5 V.N. Golosov, V.V. Ermolov, N.V. Lebedeva. Injenernie Konstruktzii [Engineering Structures: Textbook], Moscow: "Vysshaya Shkola" (1991), 408 p. (rus)

6 C. Gill, Jan Lidell, Cr. Schwitter. Straight tensioned cable roof structures, IABSE Symposium Birmingham. 1994. Pp. 221-226.

7 S.N. Krivoshapko. Suspension cable structures and roofs of erections. Construction of Unique Buildings and Structures. 2015.7 (34). Pp. 51-70. (rus).

8 K. Santoso. Wide-Span Cable Structures, Univ. of California, Berkeley. 2004. 70 p.

9 S.N. Krivoshapko. Cable-stayed structures. Structural Mechanics of Engineering Constructions and Buildings. 2016. No 1. Pp. 9-22. (rus)

10 V.K. Fedulov, M.D. Suladze, L.Yu. Artemova. Vantovie Pokrytiya [Cable-Stayed Roof Structures: Manual], Moscow: MADI (2014), 48 p., in Russian.

11 J.B. Harris, Pui-K Li Kevin. Masted Structures in Architecture, Taylor \& Francis (1996), 160 p.

12 V.A. Skopenko. Tent architecture: yesterday, today, tomorrow, Akademicheskiy Vestnik UralNIIProekt RAASN, 1 (2010), pp.30-36, in Russian.

13 S.N. Krivoshapko. Tent architecture. Stroitel'stvo i Rekonstruktsiya. 2015.59 (3). Pp. 100-109. (rus).

14 E.Yu. Ageeva, A.I. Spiridonova. Features of Application of Cable-Stayed Structures in Show Buildings, N. Novgorod: NGASU. 2015. 79 p.

15 Gupta Rajeev. Wind tunnel study on cable-stayed pavilion roofs. The Seventh Asia-Pacific Conference on Wind Engineering, Nov. 8-12, 2009, Taipei, Taiwan, 8 p.

16 A.A. Smirnov. Architecture, Structure and Design. 2017. https:design-union.ru

17 L. Zordan, R. Morganti. Large roofs, large spaces. Suspended cable roofing in Italy 1948-1970, Proc. of the First Int. Congress on Construction History, Madrid, 20 $0^{\text {th }}-24^{\text {th }}$ January. 2003. Pp. 2139-2148. 
18 Cable-stayed structures. International Database and Gallery of Structures. 2017. https://structurae.net/structures/buildings/cable-stayed-structures.

19 Y. Bescout, S. Huret, F. Millot. Stade Atatürk d'Istanbul. Construction Metallurque. 2002. 1.

20 M. Lau, K.V. Tan, C.C. Fong. The design and construction of cable-stayed steel roof structures for Yishun Indoor Stadium and Sport Complex. Singapore: The Structural Engineer. 1993. Vol. 71, Iss. 13.

21 Ilgiz Yusupov. The application of modulus of strength analysis APM Structure3D for calculating of building structures working in rigorous climatic conditions. SAPR i Grafika. 2000. 8. (rus).

22 Vintage British high tech. CMU Architecture. 2013. Jule 09. https://cmuarch2013.wordpress.com/2009/07/09/vintage-british-high-tech/

23 Nick Goldsmith. Materials for the new Millennium. In the book: Widespan Roof Structures. Compiled by M. Barnes and M. Dickson. Univ. of Bath. Thomas Telford Ltd., London. 2000.

24 I.S. Kosenko Visyachie Konstruktzii Pokrytiy [Suspended Roof Structures]. Moscow: Stroyizdat. 1966. 88 p. (rus).

25 Kenneth Powell, Richard Rogers. Complete Works. Vol. One. London: Phaidon Press Limited. 2000.

26 Marko Đuran, Ivan Lukačević, Darko Dujmović. Linear and non-linear analyses of cable-stayed steel frame subjected to seismic actions. Electronic Journal of the Faculty of Civil Engineering Osijek-e-GFOS. 2017. 8(14). Pp. 68-78. Doi: 10.13167/2017.14.8

27 Changhua Wei and Yi Sun. Philosophy of structure: How Tensile Structure Works: http://www.arch.mcgill.ca/prof/sijpkes/arch374/winter2002/psyisun/howtensileworks.htm

28 I.R. Sitnikov, A.V. Golikov Adjustment of forces in large-span structures in the design of a rational constructive form of a dolphinarium in Volgograd. Structural Mechanics of Engineering Constructions and Buildings. 2018. No 4. Pp. 278-292. (rus).

29 S. Gerasimidis, C.C. Baniotopoulos. Disproportionate collapse analysis of cable-stayed steel roofs for cable loss. Int. J. of Steel Structures. 2011. 11(1). Pp. 91-98.

30 A. Morita, K. Sato, K. Tsutsumi, Yu. Tamura. Wind load evaluation for a cable-stayed roof structure, AIJ Journal of Technology and Design. 2007. Vol. 13. No 25. Pp. 85-90. (Japanese).

31 K. Grębowski, M. Werdon. Cable-stayed cantilever structures as an expat of unique application in the construction of a building located in seismic area - an author's project of multifunctional building in Lisbon, Portugal, Int. J. of Applied Mechanics and Engineering. 2015. 20(4). Pp. 805-816.

32 A.D. Nugumanova, G.G. Kashevarova. Computation of cable-stayed constructions on the example of anchor stays, Vestnik PNIPU. Stroitelstvo i Architectura. 2015. No 3. Pp. 103-115.

33 Fabric Structures in Architecture, Ed. by J.Ig. de Llorens, The Textile Institute, Elsiver Ltd, UK. 2015. 823

p.

34 Zenon JGN del Prado, B. Paulo, Goncalves Eulher Chaves Carvalho. Non-linear dynamic of cable-stayed masts, Proc. of PACAM XI, Jan. 04-08. 2010. Foz do Iguacu, PR Brazil, 6 p.

35 Göppert Knut, Haspel Lorenz. National Stadium Warsaw, Poland. Structural Engineering International.

2013. 23(3). Pp. 311-316(6).

36 M. Saitoh. Resent development of space structures in Japan. Journal of the IASS. 2001. 42(1-2). Pp. 33-94.

37 D.B. Kiselev. Combined (hybrid) arch-cable structures. Numeric and experimental researches. Modern Industrial and Civil Construction. 2006. 2(1). Pp. 17-27. (rus)

38 P.G. Yeremeyev, D.B. Kiselev. Contemporary large-span combined spatial structures. Prostranstvennie Konstruktsii Sdaniy i Sooruzhemiy, 9, Moscow: "Devyatka Print”, 2004. Pp. 158-166. (rus)

39 V.K. Kachurin, A.V. Bragin, B.G. Erunov. Proektirovanie Visyachih i Vantovyh Mostov [Design of suspended and cable-stayed bridges]. Moscow: Izd-vo "Transport", 1971. 280 p. (rus)

40 V.K. Kachurin. Teoriya Visyachih System, Staticheskiy Raschot [Theory of Suspended Systems. Static Analysis], Leningrad: Gosstroyizdat. 1962. 224 p. (rus)

41 Olfat Sarhang Zadeh. Comparison Between Three Types of Cable Stayed Bridges Using Structural Optimization, Electronic Thesis and Dissertation Repository. 2012. 897. 100 p.: http://ir.lib.uwo.ca/etd/897

42 A.V. Perelmuter. Bases for Cable-Rod Systems Analysis, Moscow: Stroyizdat. 1969. 193 p. (rus)

43 H.B. Jayaraman, W.C. Knudson. A curved element for the analysis of cable structures. Comput. \& Struct. 1983. 14(3 / 4). Pp. 325-333.

44 A.K. Rehan. Cable suspended roof construction. Indian Concrete J. 1980. 54(4). Pp. 96-101. $549-554$

45 F. Aboul-Ella. New iterative analysis of cable-stayed structures. Computers \& Structures. 1991. 40(3). Pp.

46 Sang-Youl Lee. Detection of tensile forces in cable-stayed structures using the advanced hybrid microgenetic algorithm. International Journal of Architectural and Environmental Engineering. 2014. 8(7). Pp. 821-824.

47 Giuseppe Vairo. A closed-form refined model of the cables' nonlinear response in cable-stayed structures. Mechanics of Advanced Materials and Structures. 2009. 16(6). Pp. 456-466.

48 Nguyen Tuong Lai, Phung Ba Thang. A method for static analysis of cable-stayed structures subjected to in-plane loads. Resilient Structures and Sustainable Construction, Edited by Pellicer E., Adam J. M., Yepes V., Singh A., and Yazdani S. 2017. Pp. 1-6. 
49 Giuseppe Vairo, Sami Montassar. Mechanical modelling of stays under thermal loads. Mechanics, Models and Methods, Springer-Verlag Berlin Heidelberg, M. Fr'emond and F. Maceri (Eds.) 2012. Pp. 481-498.

50 S. Sych. Design of cable-stayed structures in Autodesk Robot Structural Analysis Professional. Cadmaster. 2012. 6. Pp. 84-86.

51 W. Schueller. The Cable in Structures Including SAP2000 (eBook). 2016. 411 p.

52 Hennig Wanda. The man who built Durban's Moses Mabhida Stadium. 2012: http://www.wandahennig.com/2012/10/the-man-who-built-durbans-moses-mabhida-stadium/

53 Jong-Son Kim. Cable-Stayed Trusses of the Sports Stadium, Chonju. Structural Engineering International, 2001. 1. Pp. 33-35.

54 A.V. Korgin, V.A. Ermakov, Zeyd Kilani L.Z., V.A. Romanets. Control of the spatial position of elements of structures of "Saint-Petersburg" stadium. Promyshlennoe i Grazhdanskoe Stroitel'stvo. 2018. No 5. Pp. 22-26. (rus).

55 Gonzalez Quelle Iago. Cable roofs. Evolution, classification and future trends. Proc. of the IASS Symposium 2009, Valencia, Evolution and Trends in Design, Analysis, and Construction of Shell and Spatial Structures, 28 Sept.-2 Oct. 2009, Universidad Politecnica de Valencia, Spain, Al. Domingo and C. Lazaro (eds.) 2009. 12 p.

56 Gehan A. Hamdy, Emad A. El-Dardiry, Mohamed N. Fayed, and Mohamed R. Konswoah. Optimum design of wide span cable-stayed roof structures. International Journal of Scientific \& Engineering Research, 9(5), (May 2018), pp.1448-1459.

57 Philip Dilley. Oxford ice rink. The ARUP Journal. 1986. 21(1). Pp. 23-26.

58 N.G. Kelasyev. Features of design and construction of a Multifunctional Sport Complex - Football Stadium for 45000 Spectators in Rostov-on-Don. Promyshlennoe i Grazhdanskoe Stroitel'stvo. 2018. No 6. Pp. 17-23. (rus).

\section{СПИСОК ЛИТЕРАТУРЫ}

1 Bradshaw R., Campbell D., Gargari M., Mirmiran A., Tripeny P. Special structures: Past, present, and future// Journal of Structural Engineering, June (2002), pp. 691-709.

2 Majowiecki M. Tensostructture: progetto e verifica // CREA edition (1985).

3 Загорков А.А. Тектоника вертикальной опоры // АМИТ. 2012. 3(20). 19 с.

4 Kloiber L.A., Eckmann D.E., Meyer Th.R., Hautzinger St.J. Design considerations in cable-stayed roof structures// North American Steel Construction: Conference: Modern Steel Construction (March 2004), pp. 75-84.

5 Голосов В.Н., Ермолов В.В., Лебедева Н.В. и др. Инженерные конструкции: Уч. для вузов по спец. «Архитектура». М.: «Высшая школа», 1991. 408 с.

6 Gill C., Lidell Jan, Schwitter Cr. Straight tensioned cable roof structures// IABSE Symposium Birmingham. 1994, pp. 221-226.

7 Кривошапко С.Н. Висячие тросовые конструкции и покрытия сооружений// Строительство уникальных зданий и сооружений. 2015. № 7 (34). С. 51-70.

8 Santoso K. Wide-Span Cable Structures, Univ. of California, Berkeley (2004), 70 p.

[9] Кривошапко С.Н. Вантовые структуры// Строительная механика инженерных конструкций и сооружений. 2016. № 1. С. 9-22. 2014. 48 c.

10 Федулов В.К., Суладзе М.Д., Артемова Л.Ю. Вантовые покрытия: Учебное пособие. М.: МАДИ,

11 Harris J.B., Pui-K Li Kevin. Masted Structures in Architecture, Taylor \& Francis. 1996. 160 p.

12 Скопенко В.А. Тентовая архитектура: вчера, сегодня, завтра// Академический вестник УралНИИПроект РААСН. 2010. № 1. С. 30-36.

13 Кривошапко С.Н. Тентовая архитектура// Строительство и реконструкция. 2015. № 3(59). С. $100-109$.

14 Агеева Е.Ю., Спиридонова А.И. Особенности применения вантовых конструкций в зрелищных зданиях. Н.Новгород: НГАСУ, 2015. 79 с.

15 Gupta Rajeev. Wind tunnel study on cable-stayed pavilion roofs. The Seventh Asia-Pacific Conference on Wind Engineering. 2009 Nov. 8-12, Taipei, Taiwan, 8 p.

16 Смирнов А.А. Архитектура, конструкция и проект. 2017. design-union.ru

17 Zordan L., Morganti R. Large roofs, large spaces. Suspended cable roofing in Italy 1948-1970// Proc. of the First Int. Congress on Construction History, Madrid, 20 $0^{\text {th }}-24^{\text {th }}$ January (2003), pp. 2139-2148.

18 Cable-stayed structures. International Database and Gallery of Structures,

https://structurae.net/structures/buildings/cable-stayed-structures (2017).

19 Bescout Y., Huret S., Millot F. Stade Atatürk d'Istanbul// Construction Metallurque. 2002. 1.

20 Lau M., Tan K.V., Fong C.C. The design and construction of cable-stayed steel roof structures for Yishun Indoor Stadium and Sport Complex, Singapore// The Structural Engineer. 1993. 71 (13).

21 Юсупов Ильгиз. Использование модуля прочностного анализа АРM Structure3d для расчета строительных конструкций в условиях сурового климата// САПР и графика. 2000. 8.

22 Vintage British high tech, CMU Architecture, (2013), Jule 09, https://cmuarch2013.wordpress.com/2009/07/09/vintage-british-high-tech/ 
23 Goldsmith Nick. Materials for the new Millennium// In the book: Widespan Roof Structures. Compiled by M. Barnes and M. Dickson. Univ. of Bath. Thomas Telford Ltd., London (2000).

24 Косенко И.С. Висячие конструкции покрытий. М.: Стройиздат, 1966. 88 с.

25 Powell Kenneth, Rogers Richard. Complete Works. Vol. One. London: Phaidon Press Limited (2000).

26 Đuran Marko, Lukačević Ivan, Dujmović Darko. Linear and non-linear analyses of cable-stayed steel frame subjected to seismic actions// Electronic Journal of the Faculty of Civil Engineering Osijek-e-GFOS, 8(14) (2017), pp. 68-78,doi.org/10.13167/2017.14.8

27 Changhua Wei and Yi Sun. Philosophy of structure: How Tensile Structure Works: http://www.arch.mcgill.ca/prof/sijpkes/arch374/winter2002/psyisun/howtensileworks.htm

28 Ситников И.Р., Голиков А.В. Регулирование усилий в большепролетных конструкциях при разработке рациональной конструктивной формы здания дельфинария в Волгограде// Строительная механика инженерных конструкций и сооружений. 2018. 4. С. 278-292.

29 Gerasimidis S., Baniotopoulos C.C. Disproportionate collapse analysis of cable-stayed steel roofs for cable loss// Int. J. of Steel Structures, 11(1), 2011, pp. 91-98.

30 Morita A., Sato K., Tsutsumi K., Tamura Yu. Wind load evaluation for a cable-stayed roof structure// AIJ Journal of Technology and Design, Vol. 13, No 25 (2007), pp. 85-90, in Japanese.

31 Grębowski K., Werdon M. Cable-stayed cantilever structures as an expat of unique application in the construction of a building located in seismic area - an author's project of multifunctional building in Lisbon, Portugal// Int. J. of Applied Mechanics and Engineering. 2015. 20(4). pp. 805-816.

32 Нугуманова А.Д., Кашеварова Г.Г. Расчет вантовых конструкций на примере оттяжек мачты // Вестник ПНИПУ. Строительство и архитектура (Пермь). 2015. № 3. С. 103-115.

33 Fabric Structures in Architecture, Ed. by J.Ig. de Llorens, The Textile Institute, Elsiver Ltd, UK (2015), 823

p.

34 Zenon JGN del Prado, B. Paulo, Goncalves Eulher Chaves Carvalho. Non-linear dynamic of cable-stayed masts// Proc. of PACAM XI, Jan. 04-08 (2010), Foz do Iguacu, PR Brazil, 6 p.

35 Göppert Knut, Haspel Lorenz. National Stadium Warsaw, Poland// Structural Engineering International, 2013. 23(3). Pp. 311-316(6).

36 Saitoh M. Resent development of space structures in Japan// Journal of the IASS. 2001. 42(1-2).Pp. 33-94.

37 Киселев Д.Б. Арочно-вантовые комбинированные конструкции. Численные и экспериментальные исследования// Современное промышленное и гражданское строительство. 2006. Том. 2. № 1. С. 17-27.

38 Еремеев П.Г., Киселев Д.Б. Современные большепролетные комбинированные пространственные конструкции// Пространственные конструкции зданий и сооружений. Вып. 9. М.: ООО “Девятка Принт”, 2004. C. 158-166.

39 Качурин В.К., Брагин А.В., Ерунов Б.Г. Проектирование висячих и вантовых мостов. Изд-во «Транспорт», 1971.280 с.

40 Качурин B.K. Теория висячих систем. Статический расчет. Л.: Госстройиздат, 1962. 224 с.

41 Olfat Sarhang Zadeh. Comparison Between Three Types of Cable Stayed Bridges Using Structural Optimization, Electronic Thesis and Dissertation Repository. 897, (2012), 100 p.: http://ir.lib.uwo.ca/etd/897

42 Перельмутер А.В. Основы расчета вантово-стержневых систем. М.: Стройиздат, 1969. 193 с

43 Jayaraman H.B., Knudson W.C. A curved element for the analysis of cable structures// Comput. \& Struct. 1981. 14(3 / 4). Pp. 325-333.

44 Rehan A.K. Cable suspended roof construction// Indian Concrete J. 1980. 54(4). Pp. 96-101. 549-554.

45 Aboul-Ella F. New iterative analysis of cable-stayed structures// Computers \& Structures. 1991. 40(3). Pp.

46 Sang-Youl Lee. Detection of tensile forces in cable-stayed structures using the advanced hybrid microgenetic algorithm// International Journal of Architectural and Environmental Engineering. 2014. 8(7). Pp. 821-824.

47 Giuseppe Vairo. A closed-form refined model of the cables' nonlinear response in cable-stayed structures// Mechanics of Advanced Materials and Structures. 2009. 16(6). Pp. 456-466.

48 Nguyen Tuong Lai, Phung Ba Thang. A method for static analysis of cable-stayed structures subjected to in-plane loads// Resilient Structures and Sustainable Construction, Edited by Pellicer E., Adam J. M., Yepes V., Singh A., and Yazdani S. (2017), pp. 1-6.

49 Vairo Giuseppe, Montassar Sami. Mechanical modelling of stays under thermal loads// Mechanics, Models and Methods, Springer-Verlag Berlin Heidelberg, M. Fr'emond and F. Maceri (Eds.), 2012, pp. 481-498.

50 Сыч С. Проектирование вантовых конструкций в Autodesk Robot Structural Analysis Professional// Cadmaster. 2012. № 6. C. 84-86.

51 W. Schueller. The Cable in Structures Including SAP2000 (eBook). 2016. 411 p.

52 Hennig Wanda. The man who built Durban's Moses Mabhida Stadium. 2012: http://www.wandahennig.com/2012/10/the-man-who-built-durbans-moses-mabhida-stadium/

53 Jong-Son Kim. Cable-Stayed Trusses of the Sports Stadium, Chonju// Structural Engineering International. 2001. 1. Pp. 33-35. 
54 Коргин А.В., Ермаков В.А., Зейд Килани Л.З., Романец В.А. Контроль пространственного положения элементов конструкций стадиона “Санкт-Петербург”// Промышленное и гражданское строительство. 2018. № 5. С. 22-26.

55 Gonzalez Quelle Iago. Cable roofs. Evolution, classification and future trends// Proc. of the IASS Symposium 2009, Valencia, Evolution and Trends in Design, Analysis, and Construction of Shell and Spatial Structures, 28 Sept.-2 Oct. 2009, Universidad Politecnica de Valencia, Spain, Al. Domingo and C. Lazaro (eds.). 2009.12 p.

56 Gehan A. Hamdy, Emad A. El-Dardiry, Mohamed N. Fayed, and Mohamed R. Konswoah. Optimum design of wide span cable-stayed roof structures// International Journal of Scientific \& Engineering Research, 9(5), May 2018, pp.1448-1459.

57 Dilley Philip. Oxford ice rink// The ARUP Journal, 21(1), 1986, pp. 23-26.

58 Келасьев Н.Г. Особенности проектирования и строительства многофункционального спортивного комплекса - футбольного стадиона на 45000 зрителей в Ростове-на-Дону // Промышленное и гражданское строительство. 2018. № 6. С. 17-23.

\section{Information about authors:}

\section{Krivoshapko Sergey N.}

Peoples' Friendship University of Russia (RUDN University), Moscow, Russia, DSc, Professor,

E-mail: sn_krivoshapko@mail.ru

\section{Информация об авторах:}

\section{Кривошапко Сергей Николаевич}

Российский университет дружбы народов, Москва, Россия, доктор технических наук, профессор,

sn_krivoshapko@mail.ru 